NBER WORKING PAPER SERIES

\title{
THE NEGATIVE TRADE-OFF BETWEEN RISK AND INCENTIVES: EVIDENCE FROM THE AMERICAN WHALING INDUSTRY
}

\author{
Eric Hilt \\ Working Paper 11960 \\ http://www.nber.org/papers/w11960 \\ NATIONAL BUREAU OF ECONOMIC RESEARCH \\ 1050 Massachusetts Avenue \\ Cambridge, MA 02138 \\ January 2006
}

I would like to acknowledge the helpful comments of Claudia Goldin, Carola Frydman, Phillip Levine, Petra Moser, and seminar participants at the NBER Summer Institute, Northwestern University, and Colby College. Dubravka Colic, Mahnaz Islam, and Erisha Suwal provided superb research assistance. I would also like to thank Michael Dyer and Laura Pereira of the New Bedford Whaling Museum for their helpful insights and assistance. All remaining errors are my own. The views expressed herein are those of the author(s) and do not necessarily reflect the views of the National Bureau of Economic Research.

(C2006 by Eric Hilt. All rights reserved. Short sections of text, not to exceed two paragraphs, may be quoted without explicit permission provided that full credit, including ( $)$ notice, is given to the source. 
The Negative Trade-off Between Risk and Incentives: Evidence from the American Whaling Industry

Eric Hilt

NBER Working Paper No. 11960

January 2006

JEL No. N5, L2, J3

\begin{abstract}
$\underline{\text { ABSTRACT }}$
This paper analyzes the trade-off between risk and incentives in the share contracts of the American whaling industry. Using a newly-collected panel of 5,378 individuals who sailed on whaling voyages from 1855-68, the response of sailors' compensation to an increase in risk is estimated. The risks used to identify this response resulted from the commerce-raiding naval vessels of the Confederacy during the Civil War. As the Confederate cruisers sailed primarily in the Atlantic, and therefore posed far less of a threat to whaling voyages to other oceans, a quasi-experimental approach, focussing on the differences between Atlantic voyages compared to others, is implemented. The results support the existence of a negative trade-off between risk and incentives in the industry's contracts. Moreover, evidence is found of selection among less risk-averse sailors and merchants into riskier voyages during the war.

Eric Hilt

Wellesley College

Department of Economics

106 Central Street

Wellesley, MA 02481

and NBER

ehilt@wellesley.edu
\end{abstract}


In the standard theory of contracts, compensation systems must balance the conflicting objectives of risk sharing, and the provision of incentives. Considerable empirical research has tested for the implied risk-incentive trade-off in contracts from a variety of contexts, both in the present and in history. In general, the results of this literature have been weak and contradictory, and in some cases, evidence of a positive relationship has been found. ${ }^{1}$ However, as a few recent contributors to this literature have noted, the trade-off between risk and incentives is difficult to identify empirically, because changes in the level of risk may induce changes in other determinants of contracts. For example, Ackerberg and Botticini (2002) argue that the riskiness of an enterprise may be correlated with the characteristics of the agents who self-select into that enterprise, while the model of Prendergast (2002) shows that risk may influence the extent of delegation between firms and employees, which may, in turn, influence the optimal choice of incentives. The weak and contradictory nature of the evidence on the relationship between risk and incentives may be due to these other responses to risk, rather than to a failure of the theory itself.

This paper analyzes the trade-off between risk and incentives in the employment contracts of the nineteenth-century American whaling industry, whose records present a unique opportunity to address these issues carefully. Whaling merchants, who resided in small ports in the northeastern United States, sent their vessels to distant oceans, where the crews had to perform many difficult and dangerous tasks, with some "too horribly nauseous for description." ${ }^{2}$ In response to the moral hazard problems inherent in their relationship with their crews, whaling merchants compensated them with incentive contracts, wherein every crewmember was given a share of his vessel's output; as an eighteenth-century merchant wrote, "we have our men on shares that all the men on board may have an interest in the success of the voyage." 3

The labor contracts of whaling voyages recorded the identity, rank, and the share of output of each crewmember, along with the identity of the merchant who sponsored the voyage. The analysis of this paper exploits the repeated observations of individual sailors and merchants on voyage contracts over time, so that the effect of changes in risk on

\footnotetext{
${ }^{1}$ See the references cited in Chiappori and Salanie (2003) and Prendergast (2002).

${ }^{2}$ Nordhoff $(1895$, p. 129). The processes of "cutting in"-flensing the blubber from the carcass of a dead whale - and "trying out" - rendering the oil from the blubber - entailed many such nauseous tasks. A detailed narration of these processes is presented in Browne (1846), who compared the shipboard scene of trying-out to "Dante's pictures of the infernal regions" (p. 63).

${ }^{3}$ Micajah Coffin (1773).
} 
the crewmembers' compensation can be identified in a panel data framework with sailorspecific and merchant-specific effects. The effect of self-selection among the industry's principals (merchants) and agents (sailors) in response to risk can therefore be isolated, and compared to those predicted by theory. The dataset collected for the paper includes all extant contracts from voyages departing in the years $1855-68$, for a total of 1,156 voyages managed by 168 merchants, and includes 5,378 different individuals, who served in the managerial ranks on board. Data describing the vessels, crews, and output of most of the voyages in the dataset were obtained from other sources, to investigate other potential responses to risk such as changes in the size or configuration of the vessels employed.

The time span of the dataset encompasses a period of elevated risks for many whaling voyages: the American Civil War. During the war, the Confederacy sent out naval cruisers in pursuit of the commercial vessels of the Union, including its whalers. The Confederate cruisers threatened the livelihoods, but not the lives, of the crews of whaling vessels, and when they captured a ship they would usually burn it with everything on board, while keeping its crew safe from physical harm. The naval efforts of the Confederacy thus created a new source risk for whaling voyages. However, the extent to which the many whaling voyages of the war years faced these risks varied substantially. In particular, the Confederate raiders sailed primarily in the Atlantic Ocean, which exposed whaling voyages in the Atlantic to the risk of capture to a much greater extent than those cruising in other seas. The identification strategy of the paper focuses on measuring the impact of this increase in risk using a difference-in-differences approach: the change in the difference between shares paid on Atlantic voyages and other voyages during the Civil War (compared to the pre-war and post-war periods) is computed.

The form of the incentive contracts used in nineteenth-century whaling resembles those envisaged by standard models of contracting under moral hazard, with a share of output (plus some additional compensation) negotiated prior to the voyage. The implications from theory for the response of these contracts to an increase in risk are therefore clear and direct: the crews' shares of output should have decreased, and the fixed component of their pay should have adjusted to compensate for their lower expected compensation. The results of this paper provide clear support for the existence of a negative trade-off between risk and incentives in whaling employment contracts: in response to the risks of the Confederate 
cruisers, the crews' output shares fell, while a guaranteed component of their compensation, which came partly in the form of advances at the beginning of the voyage, increased. ${ }^{4}$ The perceived risks associated with the Confederate cruisers in the Atlantic, which varied over the course of the war, can be quantified using marine insurance data. The results indicate that the year when the relative war risks of the Atlantic were perceived to be highest (1863) was also the year in which the relative shares paid on Atlantic voyages fell the most. These results are robust to the inclusion of fixed effects for the individual crewmembers and merchants in the dataset. Moreover, the biases resulting from excluding these fixed effects from the analysis are consistent with self-selection among less risk-averse crewmembers and merchants into riskier voyages during the war.

Although the American whaling industry and its contracts have been the subject of considerable economic research, the experience of whaling during the Civil War has not been analyzed carefully. ${ }^{5}$ This paper utilizes the extensive customs records, accounting ledgers, insurance policies, and trade papers which survive from this period to show that, at least within the managerial ranks from which the dataset was collected, the compensation contracts of the whaling industry responded to changes in risk in exactly the way predicted by theory. As the institution of paying whaling crews in shares has been characterized as little more than a "foul system of exploitation," this conclusion is quite surprising. ${ }^{6}$

The paper proceeds as follows. In the next section, a simple illustration of the effects of selection and other possible responses to risk that may confound the identification of the risk-incentive trade-off in the industry's contracts is presented. This is followed, in Section 2 , with a discussion of the impact of the Civil War on the whaling industry. Section 3 discusses the dataset collected for the paper, and Section 4 presents the empirical analysis. Section 5 evaluates several alternative explanations of the results. A Data Appendix, which presents additional detail on the sources, definitions, and descriptive statistics of the dataset,

\footnotetext{
${ }^{4}$ These advances were effectively loans against the wages to which the crews would be entitled from their shares of output. However, if the crews did not earn wages sufficient to repay their advances (for example, because the voyage went poorly or because a Confederate cruiser captured their vessel) then these advances were not repaid. See the discussion below.

${ }^{5}$ Among the many notable contributions to the study of whaling are Ellickson (1989); Hohman (1928); Allen and Keay (2004); and Davis, Gallman and Gleiter (1997). The latter study's large sample of whaling voyages excludes the Civil War era.

${ }^{6}$ Morison (1979, p. 319). As the work of Hohman (1928), Kindleberger (1992), and others have shown, however, the market for unskilled seamen on whaling voyages functioned quite differently, and for lowerranking crewmembers Morison's characterization may in fact be more appropriate. Davis, Gallman and Glieter (1997) take up the topic of market efficiency in whaling.
} 
is presented following the conclusion.

\section{Risk, Selection, and Contracts: A Simple Framework}

Most of the literature analyzing the contractual response to risk assumes a risk-neutral principal and a risk-averse agent. In whaling, however, the principal was an individual merchant (or a small partnership of merchants), rather than a risk-neutral firm, which suggests that self-selection among principals on the basis of their own risk aversion may have been important. ${ }^{7}$ In addition, whaling merchants could choose to configure their voyages in different ways, for example employing vessels and crews of different sizes. In this section, I present a simple illustration of the consequences of these potential responses to risk for the relationship between risk and incentives that is observed in the compensation contracts of the whaling industry. By examining the determinants of contracts implied by theory, some simple predictions for the direction of the bias resulting from excluding these factors from the analysis can be obtained. These predictions will then be evaluated in the empirical analysis that follows.

A simple one-period principal-agent framework, with the standard (strong) assumptions used to generate closed-form solutions and simple comparative statics, will suffice for this purpose. ${ }^{8}$ So consider a principal, who owns an enterprise, and an agent who will manage it, and whose efforts are not observed by the principal. Assume both the agent and the principal are risk averse with negative-exponential utility, and coefficients of absolute risk aversion $\rho_{a}$ and $\rho_{p}$, respectively. Output from the enterprise is given by $y=e \gamma+\epsilon$, where $e$ is the agent's effort; $\gamma$ is the marginal productivity of the agent's effort; and $\epsilon$ is a source of risk, where $\epsilon \sim N\left(0, \sigma^{2}\right)$. The agent experiences a cost of effort equal to $\frac{e^{2}}{2}$, and has a reservation level of utility given by $\bar{u}$.

The principal offers the agent a linear contract, of the form $w=b_{0}+b_{1} y$. With the given assumptions, the slope of this linear sharing rule would take the form

$$
b_{1}=\frac{\gamma^{2}+\rho_{p} \sigma^{2}}{\gamma^{2}+\left(\rho_{p}+\rho_{a}\right) \sigma^{2}}
$$

which apportions the risks of the enterprise between the principal and the agent according

\footnotetext{
${ }^{7}$ Hilt (2006) analyzes the structure and responsibilities of whaling merchant firms.

${ }^{8}$ In general, these assumptions follow Holmstrom and Milgrom (1987).
} 
to their degrees of risk aversion. ${ }^{9}$ The guaranteed component of the agent's compensation will be set to ensure that the agent receives his reservation utility, which implies that

$$
b_{0}=\bar{u}+\frac{1}{2} b_{1}^{2}\left(\rho_{a} \sigma^{2}-\gamma^{2}\right)
$$

These expressions exhibit the familiar trade-off between risk and incentives; for given levels of $\gamma, \rho_{p}$, and $\rho_{a}$, in response to an increase in $\sigma^{2}, b_{1}$ would decrease, and $b_{0}$ would likely increase. $^{10}$

However, the values of $\gamma, \rho_{p}$, and $\rho_{a}$ may vary with $\sigma^{2}$. The first mechanism through which this dependence may arise is self-selection among principals and agents. Ackerberg and Botticini's (2002) analysis of what they call "endogenous matching" among agents, for example, suggests that less risk-averse agents will select into riskier enterprises, giving rise to a negative relationship between $\sigma^{2}$ and $\rho_{a}$. Because less risk-averse agents receive higher shares $\left(\frac{\partial b_{1}}{\partial \rho_{a}}<0\right)$, this would introduce a positive bias in the estimated relationship between risk and incentives - that is, an understatement of the degree of the negative trade-off-in the shares of output, if agent characteristics are omitted from the analysis. As it is likely that less risk-averse agents receive lower guaranteed compensation $\left(\frac{\partial b_{0}}{\partial \rho_{a}}>0\right)$, if less riskaverse agents select into riskier enterprises, there would be a similar understatement of the relationship between risk and the agents' guaranteed pay. ${ }^{11}$

Selection among principals, however, could produce biases in the opposite direction. Suppose that in response to an increase in risk, the more risk-averse among the principals exit or shut down their enterprises, creating a negative relationship between $\sigma^{2}$ and $\rho_{p}$. Equation (1) implies that $\frac{\partial b_{1}}{\partial \rho_{p}}>0$, so if merchants who were more willing (or perhaps better able) to bear risks become more prevalent, then the shares paid to crews on riskier voyages should have fallen, as these merchants would optimally bear a larger fraction of their voyages' risks. Thus, if principal characteristics are neglected from the empirical analysis

\footnotetext{
${ }^{9}$ This is the share that maximizes the total certainty-equivalent payoffs of the principal and the agent, or $e \gamma-\frac{e^{2}}{2}-\frac{1}{2} \rho_{a} b_{1}^{2} \sigma^{2}-\frac{1}{2} \rho_{p}\left(1-b_{1}\right)^{2} \sigma^{2}$, subject to the first-order condition for the agent's effort choice, $e=b_{1} \gamma$.

${ }^{10}$ The response of the shares of output to an increase in risk is unambiguous - $\frac{\partial b_{1}}{\partial \sigma^{2}}<0$. However, $\frac{\partial b_{0}}{\partial \sigma^{2}}=$ $b_{1}\left(\rho_{a} \sigma^{2}-\gamma^{2}\right) \frac{\partial b_{1}}{\partial \sigma^{2}}+\frac{1}{2} b_{1}^{2} \rho_{a}$. Because $\frac{\partial b_{1}}{\partial \sigma^{2}}<0$, the first term in this expression will be positive (and the sign of $\frac{\partial b_{0}}{\partial \sigma^{2}}$ free of ambiguity) so long as $\frac{\gamma^{2}}{\sigma^{2}}>\rho_{a}$. If that condition does not hold, then the agent is so risk averse that a reduction in $b_{1}$ does not make him worse off, despite the loss in his expected pay (or in other words, his indifference curve between $b_{1}$ and $b_{0}$ slopes upward.)

${ }^{11}$ Since $\frac{\partial b_{0}}{\partial \rho_{a}}=b_{1}\left(\rho_{a} \sigma^{2}-\gamma^{2}\right) \frac{\partial b_{1}}{\partial \rho_{a}}+\frac{1}{2} b_{1}^{2} \sigma^{2}$, the sign of the relationship between $b_{0}$ and $\rho_{a}$ is free of ambiguity only when $\frac{\gamma^{2}}{\sigma^{2}}>\rho_{a}$. If this condition holds, then the agent's indifference curve between $b_{1}$ and $b_{0}$ slopes downward.
} 
of the share contracts, this would introduce a negative bias in the estimated relationship between risk and incentives, or an overstatement of the degree of the negative trade-off.

A second mechanism that may generate a correlation between risk and the other contract parameters is that the principal may optimally choose to configure the enterprise, and in particular make changes in choice variables that affect $\gamma$, in response to $\sigma^{2}$. The parameter $\gamma$ will likely depend on the scale of the enterprise (see, e.g., Baker and Hall, 2004), or other variables such as the technology employed in production. Any relationship between these characteristics and risk will also therefore affect contractual incentives. Another interpretation of $\gamma$ could be that it is related to the decision-making authority of the agent. One simplistic interpretation of the general argument of Prendergast (2002) in terms of the framework presented here is that, depending on the degree of risk, the principal will optimally decide the degree of delegation of decisionmaking to the agent, which, in turn, may influence $\gamma$. If greater increases in $\gamma$ are associated with increases in risk, then because $\frac{\partial b_{1}}{\partial \gamma}>0$, omitting variables associated with $\gamma$ would introduce a negative bias in the estimated relationship between risk and incentives, overstating the degree of the negative trade-off.

In the analysis that follows, I will carefully address each of these possible sources of bias. If less risk-averse sailors and merchants selected into riskier voyages, the bias resulting from these forms of selection should go in opposite directions, with the former leading to an understatement, and the latter an overstatement, of the risk-incentive trade-off. In addition, vessel and crew characteristics, along with the ranks of each crewmember (which may determine the scope of their authority), will be included in the analysis, as potentially related to the productivity of the agents' efforts. Although the expected changes in enterprise characteristics in response to risk are less clear, if merchants configure their voyages in a way that increases the marginal productivity of the crews' effort, then omitting this would also overstate the estimated extent of the risk-incentive trade-off.

Before discussing the datset and the empirical analysis, the next section presents a brief overview of the whaling industry during the Civil War. 


\section{Whaling in the Civil War}

\subsection{The Confederate Cruisers}

The naval strategy of the Confederacy directed considerable resources to disrupting the commerce of the Union. These efforts commenced at the outbreak of the war in April 1861, as the Confederacy offered letters of marque to owners of private vessels, creating privateers. $^{12}$ Although the efforts of these privateers were short-lived ${ }^{13}$, the Confederacy also sponsored naval warships, often purchased from Britain, and employed them as commerce raiders, with considerable success throughout the war. Eight of these cruisers managed to inflict significant damage on the commercial interests of the Union, and the most successful, the CSS Alabama, captured 69 vessels during its 1862-64 cruise. $^{14}$ The Confederacy ultimately captured 251 vessels and destroyed 239 of them, which was equivalent about $5 \%$ of the tonnage registered in foreign trade in the United States. ${ }^{15}$ In response, a substantial portion of U.S. trade was shifted to the vessels of neutral powers. ${ }^{16}$

Whaling vessels were easy marks for the much larger, steam-powered Confederate cruisers. Although the itineraries of whaling voyages took them to obscure regions of the oceans, away from the routes of other commercial vessels, they were defenseless and valuable prey, and capturing them was mostly a matter of finding them. The captains of a few of the Confederate cruisers rose to this challenge, and devoted considerable energy to obtaining the intelligence necessary to locate whaling vessels. One whaling captain wrote to his ship's owners that he had learned that Captain Raphael Semmes of the CSS Alabama "has an old whaler on board who is well acquainted with all the cruising grounds and makes good use of all Shipping Lists, abstracts, charts, letters, and other sources of information." ${ }^{17}$ Re-

\footnotetext{
${ }^{12} \mathrm{~A}$ letter of marque is a license issued by a government in wartime to a privately-owned vessel to capture the vessels of enemy powers. Having obtained this license, a privateer and her crew were entitled to the same legal rights as other warships, in contradistinction to a pirate vessel, which has no rights in Admiralty law, and whose crews were often put to death if captured.

${ }^{13}$ With the increasingly effective Union blockade of Southern ports, and British neutrality, which foreclosed the use of its ports, it became impossible for Confederate privateers to sell prizes (captured vessels). After some early successes in 1861, the threat posed by privateers essentially ended in 1862 . U.S. Naval War Records Office, series I vol. I, p. 819, provides a list of known privateers, with an account of their prizes.

${ }^{14}$ Scharf (1887: 814-18) provides a comprehensive tabulation of all vessels captured by the confederate cruisers.

${ }^{15}$ The capacity of the 239 vessels destroyed was around 105,000 tons; this is equivalent to about $5 \%$ of the average annual tonnage of American vessels engaged in foreign trade during the years 1861-65 (author's cacluations from data in Nimmo, 1870 p. 9 and 44).

${ }^{16}$ Nimmo (1870: table XX) documents that the fraction of imports (by value) carried into the United States on domestically-owned vessels fell from $64 \%$ in 1860 to $25 \%$ in 1864 .

${ }^{17}$ Lewis Herendeen, letter of 16 September 1862 (at sea), to Swift \& Allen of New Bedford. In his memoirs,
} 
ports of Semmes' cruise, in which he captured 13 whalers, and those of other Confederate vessels, were followed assiduously in whaling ports, and sightings of these ships - or even rumors of sightings - were printed almost weekly in whaling newspapers. ${ }^{18}$ The Confederate raiders ultimately captured 45 whalers, equivalent to about $12 \%$ of the voyages that departed during the war. ${ }^{19}$

The Confederate cruisers - derided as an "Anglo-Slaveocrat navy" by whaling merchants $^{20}$ — were sent out to attack the commercial vessels of the Union, but not to harm their crews. When a vessel was captured, its crew was held in irons, and eventually put onboard a neutral ship or left in a neutral port, and the vessel itself, along with everything on board except what the Confederates plundered, was usually burned. ${ }^{21}$ For a whaling vessel, this meant losing the produce from which the crews' wages would be paid. ${ }^{22}$ The share contracts of the crews effectively divided this risk between the sailors and the industry's merchants. $^{23}$

The commanders of the Confederate vessels were instructed to do "the greatest injury in the shortest time" to the commerce of the North, and were provided with limited resources to do so. ${ }^{24}$ As a result, they focused their cruises on the waters near the shipping routes heavily utilized by the commercial vessels of the United States, and these were overwhelmingly in the Atlantic. This created a differential effect for commercial vessels in the Atlantic Ocean.

The merchants of American whaling ports in the mid-nineteenth century could select any of the world's oceans for their voyages, and frequently sent them as far as the icy waters north of the Arctic Circle near Alaska. However, the Atlantic, and in particular its

Semmes mentions that "whalers are obliged to congregate within small well-known spaces of ocean," making them "obvious" targets (Semmes 1869: 424).

${ }^{18}$ Examples of such articles in the Whalemen's Shipping List include "Whaleships Captured and Burned" (14 October 1862), "Destruction of Ship Golden Eagle" (14 April 1863), and "The Pirate Florida" (13 September 1864).

${ }^{19}$ See U.S. Department of State (1871).

${ }^{20}$ Whalemens Shipping List, 25 August 1863.

${ }^{21}$ The narratives of the captains of captured whaling vessels describe rough but fair treatment at the hands of the Confederates; see, for example, Whalemens Shipping List, "Captain Winslow's Statement," 9 August 1864; "Arrival of the Officers and Crews of the Pirate Alabama," 4 November 1864; and "Letter of Captain Potter of the Oneida" 9 June 1863.

${ }^{22}$ Insurance was sometimes obtained on catchings during the voyage, but this was usually done by the vessel owners to cover only their share, or more typically part of their share. The cases adjudicated by the Courts of Commissioners of Alabama Claims include large awards to crews for uninsured oil destroyed when their vessel was burned.

${ }^{23} \mathrm{~A}$ related but different consequence of capture was the loss of the vessel itself, but this risk was borne by the merchants sponsoring the voyage, and not the crews, and was more frequently covered by insurance.

${ }^{24}$ Instructions of the Confederate Navy to the commander of the CSS Florida, 14 July 1862, in U.S. Naval War Records Office, Series I vol. 1, 1894. 
central and southern regions, remained an attractive destination for whaling voyages, as its proximity to the ports of New England, coupled with its resilient populations of sperm whales, made it a productive and less costly destination for whaling voyages. ${ }^{25}$ All whaling voyages originating from the northeastern United States faced the danger of capture by the Confederates on their outbound and returning passages. But vessels that remained within the Atlantic for the duration of their voyages were exposed to this danger to a much greater extent. The far reaches of the Pacific, in contrast, were regarded as a safe refuge from the Confederates, too distant and too sparse with vessels to make an effective commerceraiding cruise. In reporting on Captain Semmes of the Alabama, a contemporary journalist echoed this sentiment, writing that "He might make a raid on our whalers, and he says he is particularly anxious to cripple New-England men - but the facilities for such business as his are much less on the Pacific than on the Atlantic." ${ }^{26}$ One whaling merchant echoed this assessment as he wrote to his vessel's captain in 1863 that whaling vessels "in the Pacific have not been molested by the first pirate yet, and we very much doubt whether they will be." 27 This expectation proved mostly correct. ${ }^{28}$

The rates of marine insurance for war risks on whaling vessels also reflected a perceived differential exposure to the risks of capture throughout the war. Vessels that committed to cruise for whales only in the Pacific or Indian Oceans, and to sail swiftly through the Atlantic without pursuing whales on their outbound or inbound passages, paid less for insurance for war risks. ${ }^{29}$ The additional war premium for the Atlantic varied somewhat over the war, but reached nearly $5 \%$ per year at its peak, in $1863 .^{30}$

\footnotetext{
${ }^{25}$ The Whalemens Shipping List of 2 February 1864 notes that "short voyages to the Atlantic have been more successful" in obtaining cargoes of sperm oil in recent years.

26 "The Pirate Alabama," New York Times, 29 December 1862.

${ }^{27}$ Letter of 25 August 1863, to Captain Thomas Williams, from Swift \& Allen. The merchants of the North frequently derided the Confederate cruisers as "pirates," a contemptuous term whose meaning was similar to that of the modern word "terrorist."

${ }^{28}$ Unbeknownst to the whaling merchants of the United States, late in the war the Confederates made preparations to send a vessel into the North Pacific and Arctic Oceans with the intent of capturing the whaling fleet there. But this new vessel, the CSS Shenandoah, did not reach the Arctic until June 1865, after the Confederacy had fallen. The Shenandoah's captain did not believe reports he was given that the war had ended, and proceeded to capture 24 whalers within that month. One indication this attack was unexpected is illustrated by the large number of insurance policies covering war risks obtained by whaling merchants in July and August, 1865, when rumors that a new cruiser was venturing into the North Pacific first reached the whaling ports. (Policies contained in claims 3808, 3862, and 3866, in Court of Commissioners of Alabama Claims, 1882-85.)

${ }^{29}$ Insurance policies issued for voyages to the Pacific or Indian Oceans contained the language, "Prohibited from being more than 50 days from the day of sailing north of the Equator on the outward passage." (Policies contained in exhibits in Court of Commissioners of Alabama Claims, 1882-85.)

${ }^{30}$ See table 5 below. The added premium for Atlantic voyages was frequently discussed in the newspapers of whaling ports; see, for example, the New Bedford Republican Standard, 23 October 1862.
} 
Figure 1:

Trends in the Whaling Labor Market, 1855-68

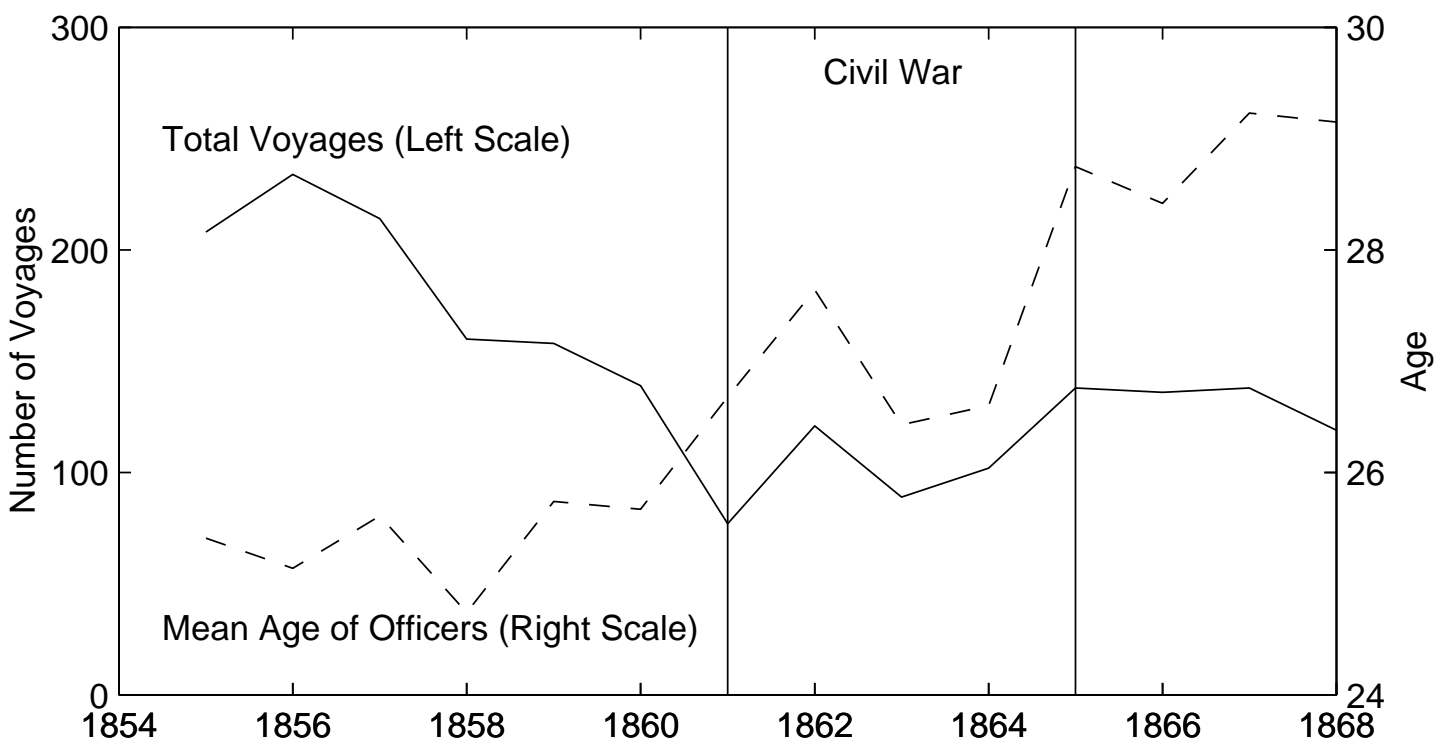

Sources: Mean age of officers is calculated as the annual average of the age of sailors in the positions of first through fourth officer, and boatsteerer, from the manuscript Seamens Registers of the New Bedford Port Society. See the discussion of the dataset below. Total voyages is calculated from data in Starbuck (1878). Note: as annual data are plotted in the figure, the full years 1861 and 1865 are included in the period denoted as the Civil War.

\subsection{Historical Context and Identification Strategy}

The outbreak of the Civil War occurred within a period of significant change in the whaling business. After enjoying sustained growth and prosperity in the second quarter of the nineteenth century, the industry began to contract in the mid-1850s. The years following the panic of 1857 were especially difficult for the industry's merchants, and in response to ruinous losses many ceased operations. ${ }^{31}$ The late 1850s saw a significant decline in the number of whaling voyages departing from American ports, as illustrated in figure 1: the number of voyages fell from more than 200 per year in the mid-1850s to around 100 during the Civil War. This decline in production improved the prospects for the merchants who remained in whaling, and the number of departing voyages stabilized. ${ }^{32}$

An illustration of the consequences of these changes for the labor market for whaling

\footnotetext{
${ }^{31}$ In a letter to a Honolulu merchant in January 1861, the whaling merchants Swift \& Allen mentioned seven different New Bedford-area whaling firms that failed in the years following the crisis of 1857 (Letter to Wilcox, Richards \& Co., 29 January 1861.)

${ }^{32}$ Merchants at the time noted that the stocks of whale commodities held by dealers fell in the early 1860s, contributing to robust prices for output. (Whalemens Shipping List, 11 October 1863.) In addition, hunting pressure on whale populations became less intense - see Davis, Gallman and Gleiter (1997, table A8.2) — raising the prospect of more productive voyages.
} 
crews is also presented in the figure. The reduction in demand for labor in the industry apparently had an impact on the composition of the individuals hired: in the late 1850s, the average age of individuals hired as officers on board whaling vessels began to rise precipitously, a trend that continued throughout the war and in the postwar period. The war had significant consequences for the supply of labor as well; significant numbers of seamen volunteered for service in the Army or Navy during the war, or were conscripted. ${ }^{33}$

The Civil War affected many aspects of the whaling business, and occurred within the context of many preexisting processes of change. The direct and indirect consequences of the war on the industry's labor markets and product markets likely influenced a number of determinants of the sailors' compensation contracts, from their reservation utilities to the productivity of their efforts. However, the disruptions created by the war were industrywide shocks, whereas there was a change in the relative level of risk between voyages to the Atlantic and other voyages, due to the predations of the Confederate cruisers. The effects of this change in risks will be identified by comparing the shares of sailors on voyages to the Atlantic with those to other oceans, during the war and in the periods adjacent to the war.

To this end, a panel dataset of whaling labor contracts was collected. The next section of the paper presents a description of this dataset.

\section{Data}

The main variables in the dataset were collected from manuscript labor contracts, known as "Whalemen's Shipping Papers," from the customs districts of New Bedford, Massachusetts and New London, Connecticut, for the years $1855-68 .^{34}$ The dataset includes 1,156 whaling voyages originating from 13 different ports, mostly in Massachusetts and Connecticut, representing $57 \%$ of all whaling voyages from the United States from this period. ${ }^{35}$ These voyages were managed by 168 different merchants.

\footnotetext{
${ }^{33}$ During the war a "Naval Rendezvous" (recruiting office) operated in New Bedford and recruited thousands of seamen (Whalemens Shipping List, 3 October 1863.) The Navy also purchased old whaling vessels and hired whaling crews to operate them on special missions wherein these vessels were scuttled in the harbors of Charleston and Savannah in the hope of making those ports inaccessible (see U.S. Naval War Records Office, Series I, vol. 6.)

${ }^{34}$ These documents are in the possession of the National Archives (Record Group 36), except for the years 1855-58 and 1866 for the customs district of New Bedford, which are in the possession of the New Bedford Free Public Library.

${ }^{35}$ Of the 877 whaling voyages not in the dataset because no contract could be found, $734(84 \%)$ originated from ports that were part of customs districts whose whaling records do not survive (mostly Barnstable, MA, and Sag Harbor, NY.)
} 
The dataset is organized as a panel of individual sailors. In order to focus on individuals who would be most likely to be observed on repeated voyages - career whalemen - the dataset was collected from the managerial ranks of each voyage: the master, who commanded the vessel; the officers or "mates," who commanded one of the small whaleboats launched from the vessel to pursue whales, and supervised the crew; and the boatsteerers, who were somewhat like the petty officers of naval vessels, and were the harpooners on the whaleboats. ${ }^{36}$ The whaling voyages in the dataset had, on average, somewhat more than seven people in these managerial ranks. For each individual in these ranks, his name, rank, share, and whether or not he was literate enough to sign his own name, was recorded. In addition, the rank, share and literacy status of all the other crewmembers was recorded. The contracts used to construct the dataset included 8,612 total agreements for these ranks, but for about $5.3 \%$ of these, the share was not specified on the contract. ${ }^{37}$

The names of the individuals in the dataset were transcribed from their signatures on the contracts, which were often difficult to decipher, due to the sailor's handwriting, or the conditions of the documents. The entries for each voyage in the dataset from the customs district of New Bedford were therefore located in the manuscript "Seamens Registers" of the New Bedford Port Society. From these volumes, the spelling of the names was corrected, and the age and appearance - complexion, and hair color - of each individual was recorded, where it was available. In constructing the panel, observations were ascribed to individuals on the basis of their names, but in cases where it was apparent that more than one sailor had the same name, these age and appearance data were used to distinguish among the different individuals; see section A.2 of the Data Appendix for details. (All observations where such assignments were made were deleted from the dataset in robustness checks, as reported below.)

The advances received by the crewmembers were not recorded on the voyage labor contracts, or on any of the other documents retained by customs houses. The only record of the advances was made within the merchants' accounts, most of which no longer sur-

\footnotetext{
${ }^{36}$ Hohman (1928) provides detailed descriptions of the production process on board whaling vessels, and the responsibilities of the various ranks. The name boatsteerer arose from the second responsibility of that rank: once they harpooned a whale, they would move to the back of the boat and steer it, while the senior officer on board, usually one of the mates, moved to the front to kill the whale using a lance.

${ }^{37}$ In many cases, especially for the master, the space in the document where their share would have been recorded was simply left blank. In other cases, however, in place of their share it was written "As per agreement." These individuals probably received, in lieu of a simple share of output, a contract that was more complex.
} 
Table 1:

Descriptive Statistics: Officers and Boatsteerers

\begin{tabular}{|c|c|c|c|c|c|c|c|c|c|c|}
\hline & \multicolumn{4}{|c|}{ Output Share, \% $(N=8,151)$} & \multicolumn{4}{|c|}{ Advance, 1855 \$'s $(N=1,004)$} & \multirow{2}{*}{$\begin{array}{c}\text { Mean } \\
\text { Age }\end{array}$} & \multirow{2}{*}{$\begin{array}{c}\% \\
\text { Illit. }\end{array}$} \\
\hline & Mean & Stdev. & Min. & Max. & Mean & Stdev. & Min. & Max. & & \\
\hline Master & 7.47 & 1.22 & 4.00 & 14.29 & - & - & - & - & - & 0.09 \\
\hline First Officer & 5.03 & 0.95 & 1.82 & 12.50 & 192.50 & 193.83 & 0 & $1,262.76$ & 31.26 & 1.65 \\
\hline Second Officer & 3.10 & 0.76 & 1.00 & 12.50 & 161.68 & 98.47 & 0 & 600.00 & 28.83 & 11.43 \\
\hline Third Officer & 2.00 & 0.38 & 1.11 & 5.00 & 133.04 & 67.61 & 0 & 429.00 & 26.89 & 18.20 \\
\hline Fourth Officer & 1.49 & 0.27 & 1.00 & 2.86 & 133.94 & 57.23 & 0 & 294.22 & 27.39 & 25.48 \\
\hline Boatsteerer & 1.27 & 0.42 & 0.67 & 5.00 & 101.13 & 40.28 & 0 & 230.29 & 24.57 & 33.10 \\
\hline Total & 2.77 & 2.15 & 0.67 & 14.29 & 127.74 & 91.08 & 0 & $1,262.76$ & 26.83 & 19.37 \\
\hline
\end{tabular}

vive. However, a sample of 1,004 advances from 187 voyages originating from the port of New Bedford was constructed from the manuscript accounting records which survive in the whaling archives in that city. These voyages are approximately representative of the overall dataset with respect to most observable voyage characteristics; see section A.3 of the Data Appendix for additional details. ${ }^{38}$

Table 1 presents summary statistics for the shares, advances, and other characteristics of the sailors in the dataset, by rank. The shares listed in the table are expressed as the percentage of the voyage's output that the sailors' shares entitled them to. On average masters received about $7.5 \%$ of the voyages' output, first officers received about $5 \%$, and the shares decreased further down the ranks. ${ }^{39}$ Turning to the advances, few records could be found regarding the advances of the masters, but the first officers received on average nearly $\$ 200$, and the lower ranks received somewhat less. ${ }^{40}$

As one might expect, the data indicate that the master and first officers, who would have been required to keep a log, read nautical charts, and sign documents, were overwhelmingly literate. In addition, as promotions were probably obtained with experience, the individuals

\footnotetext{
${ }^{38}$ The sample consists of every voyage from which records of advances could be found within the holdings of the New Bedford Whaling Museum, and the New Bedford Free Public Library.

${ }^{39}$ In general, these figures are slightly higher than those computed by Davis, Gallman and Gleiter (1997) from their sample from 1840-58 and 1866. For example, in their sample, the shares of captains, first officers, second officers, and third officers entitled them to $6.58,4.37,2.63$, and 1.76 percent of output, respectively. This is consistent with the patten they observe in their sample of rising shares paid to the officers of whaling crews over time.

${ }^{40}$ The masters' accounts with the owners of the vessel were generally kept separately from that of the rest of the crew.
} 
Table 2:

Descriptive Statistics: Voyages

\begin{tabular}{|c|c|c|c|c|c|}
\hline & Mean & Std. Dev. & Min. & $\operatorname{Max}$ & $N$ \\
\hline \multicolumn{6}{|l|}{ Master } \\
\hline Number of prior commands & 2.35 & 2.47 & 0 & 16 & 1,152 \\
\hline At least one prior command & 0.77 & - & 0 & 1 & 1,156 \\
\hline Died on voyage & 0.03 & - & 0 & 1 & 1,151 \\
\hline Share owned in vessel & 0.06 & 0.11 & 0 & 1 & 909 \\
\hline \multicolumn{6}{|l|}{ Crew } \\
\hline Total number of officers & 7.46 & 1.33 & 2 & 11 & 1,156 \\
\hline Total number in crew & 27.04 & 4.99 & 9 & 47 & 1,156 \\
\hline Percent illiterate & 27.69 & 13.99 & 0 & 78.26 & 1,156 \\
\hline Total shares, $\%$ of output & 34.82 & 3.83 & 16.99 & 63.45 & 835 \\
\hline Average share, $\%$ of output & 1.36 & 0.37 & 0.78 & 4.74 & 835 \\
\hline Number deserting before departure & 1.48 & 1.82 & 0 & 15 & 1,156 \\
\hline \multicolumn{6}{|l|}{ Vessel } \\
\hline Tonnage & 295.10 & 105.00 & 58 & 699 & 1,152 \\
\hline Rigging: Ship & 0.33 & - & 0 & 1 & 1,156 \\
\hline Rigging: Bark & 0.55 & - & 0 & 1 & 1,156 \\
\hline Rigging: Sloop or Brig & 0.12 & - & 0 & 1 & 1,156 \\
\hline \multicolumn{6}{|l|}{ Itinerary } \\
\hline Atlantic Ocean & 0.32 & - & 0 & 1 & 1,156 \\
\hline Pacific Ocean & 0.49 & - & 0 & 1 & 1,156 \\
\hline Indian Ocean & 0.17 & - & 0 & 1 & 1,156 \\
\hline \multicolumn{6}{|l|}{ Outcomes } \\
\hline Productivity index, completed voyages & 1.34 & 1.33 & -1.27 & 4.23 & 953 \\
\hline Duration (mos.), completed voyages & 35.69 & 15.54 & 1 & 83 & 962 \\
\hline Specialized in sperm oil, completed voyages & 0.46 & - & 0 & 1 & 961 \\
\hline Lost or condemned & 0.10 & - & 0 & 1 & 1,155 \\
\hline Captured by Confederates & 0.03 & - & 0 & 1 & 1,155 \\
\hline
\end{tabular}


in the more senior positions tended to be somewhat older than their subordinates. (The ages of the masters were generally not recorded on the registers from which these data were obtained.) Finally, it should be noted that $4.1 \%$ of the crewmembers in the dataset held more than one rank, with their second rank usually one of the artisan positions on board the vessel, such as the cooper, blacksmith, or carpenter, or boatsteerer.

The data on the crews for each voyage were matched to data from other sources such as Starbuck (1878) and Lund (2001), which contain information on the vessels and the voyage itineraries and outcomes, and to the vessels' registers, which list the names of the merchant sponsoring each voyage - whose role was known as the vessel's "agent" - and the other owners of the vessel. ${ }^{41}$ Table 2 provides summary statistics for the voyages included in the sample; the definitions and sources for these data are presented in section A.1 of the Data Appendix. As reported in the table, $32 \%$ of the voyages sailed to the Atlantic ocean, whereas $49 \%$ and $17 \%$ sailed to the Pacific and Indian Oceans, respectively. $10 \%$ were lost or so damaged they were "condemned" and sold in a foreign port, and $3 \%$ were captured by Confederate vessels. ${ }^{42}$ Of the 903 voyages where information could be obtained, the master owned a share in the vessel. On average, the voyages in the sample had 27 crewmembers, of which $28 \%$ were illiterate. In total, their shares entitled them to about $35 \%$ of output, and the average sailor received about $1.2 \%$.

For most of the completed voyages, their duration, whether or not they specialized in obtaining sperm oil ${ }^{43}$, and an index of their productivity, defined as the log of real output per input, where inputs are measured as vessel tons $\times$ months at sea, could be computed. Consistent with the results of Davis, Gallman and Glieter (1997), the productivity index has a very large standard deviation.

Finally, it should be noted that the time period encompassed by the sample was one of substantial entry and exit by whaling merchants, and the Civil War seems to have at least contributed to this process of change. Of the 168 different whaling merchants who managed at least one voyage in the dataset, only 37 managed voyages during the pre-war, war and

\footnotetext{
${ }^{41}$ As these "agent" merchants served as the principals in the principal-agent problem under examination in this paper, I will refer to them as merchants, rather than agents, to avoid confusion.

${ }^{42}$ The fraction of vessels captured by the Confederates appears low because the sample includes many years other than those of the Civil War. In fact, more than $15 \%$ of the vessels whose voyages began during the years 1861-64 were captured by the Confederates.

${ }^{43}$ The oil obtained from sperm whales was more valuable than that of right whales; see the discussion in Davis, Gallman and Gleiter (1997).
} 
post-war periods. 96 exited the whaling business either during the pre-war period or during the war, and 4 were active during the pre-war and post-war periods only, apparently ceasing operations during the war. (The remaining 31 merchants entered the business either during the war or after the war). This suggests that selection among the merchants may be an important determinant of the response of whaling contracts to changes in risk.

\section{Results: The Effect of the Civil War on Whaling Contracts}

Some preliminary evidence of the effect of the risks associated with the Civil War is presented in figure 2. In the figure, the dashed line plots the average within-year differences between the shares of output paid to officers on voyages to the Atlantic, compared to voyages to other oceans, controlling for ranks. Throughout the time span of the figure, the shares paid to officers on voyages to the Atlantic are higher than those of their counterparts sailing to other oceans. Although these data are quite noisy, the difference between Atlantic and other voyages appears to fall during the Civil War, and then rise again subsequently. This is consistent with decreased contractual incentives in response to higher risks, and the upturn after the war suggests that the downturn in 1861-65 is not merely an ongoing part of some preexisting and continuing trend.

A preliminary indication of the importance of selection among the individual sailors can be seen by adding sailor fixed effects to the regression used to produce figure 2 . This is plotted as the solid line in the figure. During the period of the Civil War, the solid line is far below the dashed line, and the difference between the level of the solid line in this period and the level in the pre- and postwar periods seems to increase slightly. This is consistent with less risk-averse sailors selecting onto Atlantic voyages, and implies that the dashed line understated the effect of risk on incentives.

A more careful assessment of the evidence in figure 2 is presented in table 3 , which presents regressions that test the differences in differences illustrated by the figure, along with additional specifications. In the table, regressions using variations of the following specification are presented: for a share $b$ paid to crewmember $i$ on a vessel managed by 
Figure 2:

Differences in Shares Paid to Officers, Atlantic vs. Other, in \%

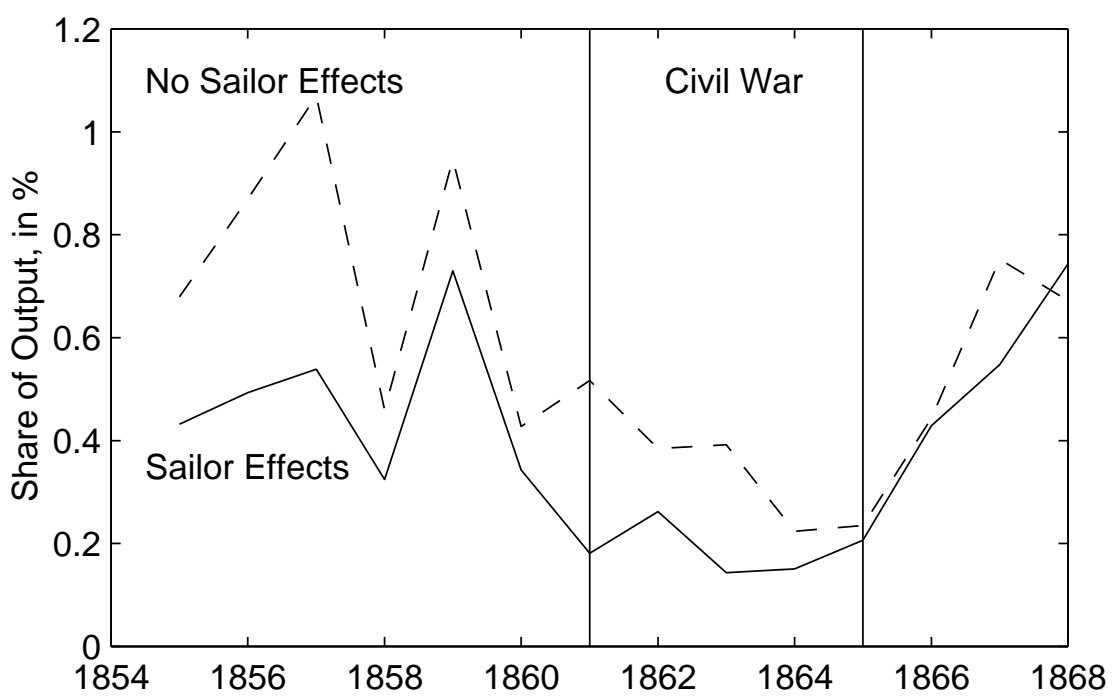

Note: The points plotted are from the regression $b_{i t}=\mathbf{r}_{i t} \theta+\sum_{t} \pi_{t}$ Atlantic $_{i t} \times$ year $_{t}+\sum_{t} \delta_{t}$ year $t+$ $\sum_{i} \nu_{i}$ sailor $_{i}+u_{i t}$, where $b_{i t}$ is the share paid to crewmember $i$ on a voyage departing in year $t$; $\mathbf{r}_{i t}$ is a vector of indicator variables for the different ranks (master, first officer, etc.), and secondary ranks (cooper, blacksmith, etc.); Atlantic $i t$ is an indicator variable for an Atlantic voyage; sailor is $_{i}$ an indicator variable for each individual sailor; and year $t_{t}$ is and indicator variable for each year. The $\pi_{t}$ 's are plotted. The specification used to generate the dashed line omits the sailor ${ }_{i}$ terms. In the figure, the full years 1861 and 1865 are included in the period denoted as the Civil War.

merchant $j$ departing in year $t$, I estimate:

$$
\begin{aligned}
b_{i j t}=\alpha_{0}+ & \mathbf{r}_{i j t} \theta+\mathbf{x}_{i j t} \beta \\
& +\alpha_{1} \text { Atlantic }_{i j t}+\alpha_{2} \text { Atlantic }_{i j t} \times \operatorname{prewar}_{i j t}+\alpha_{3} \text { Atlantic }_{i j t} \times \text { war }_{i j t} \\
& +\nu_{i}+\phi_{j}+\delta_{t}+u_{i j t}
\end{aligned}
$$

where $\mathbf{r}_{j t}$ is a vector of indicator variables for the different ranks (master, first officer, etc.), and secondary ranks (cooper, blacksmith, etc.); $\mathbf{x}_{i j t}$ is a vector of vessel and crew characteristics; Atlantic $i t$ is a binary variable for voyages to the Atlantic Ocean; $\operatorname{prewar}_{i t}$ and $\operatorname{war}_{i t}$ are binary variables for the pre-Civil War period, and Civil War period; and $\nu_{i}, \phi_{j}$ and $\delta_{t}$ are sailor, merchant, and year effects, respectively. The Civil War period is defined as April 1861-April 1865 (inclusive). ${ }^{44}$ The coefficients $\alpha_{2}$ and $\alpha_{3}$ are the differences

\footnotetext{
${ }^{44}$ The time span within which departing whaling voyages anticipated facing the danger of Confederate cruisers may have been somewhat greater than this; it may have been possible, for example, to anticipate both a war and Confederate naval activity well before the attack on Fort Sumter, and there may have been some concern about Confederate cruisers well after the surrender of General Lee and the capture of Jefferson Davis. The results presented in table 3 are robust to including the full years 1861 and 1865 within the period designated as the war; the effect of the war becomes somewhat smaller, but remains statistically significant.
} 
Table 3:

Regressions: Shares

The Dependent Variable is Share, in \% of Output

\begin{tabular}{|c|c|c|c|c|c|c|}
\hline & $(1)$ & $\overline{(2)}$ & $(3)$ & 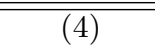 & $(5)$ & $(6)$ \\
\hline Atlantic & $\begin{array}{c}0.556^{* * *} \\
(0.117)\end{array}$ & $\begin{array}{c}0.506^{* * *} \\
(0.077)\end{array}$ & $\begin{array}{c}0.319^{* * *} \\
(0.064)\end{array}$ & $\begin{array}{c}0.124^{* * *} \\
(0.047)\end{array}$ & $\begin{array}{c}0.142^{* *} \\
(0.050)\end{array}$ & $\begin{array}{c}-0.062 \\
(0.131)\end{array}$ \\
\hline Atlantic $\times$ pre-war & $\begin{array}{c}0.178 \\
(0.172)\end{array}$ & $\begin{array}{l}-0.051 \\
(0.097)\end{array}$ & $\begin{array}{l}-0.090 \\
(0.100)\end{array}$ & $\begin{array}{l}-0.001 \\
(0.082)\end{array}$ & $\begin{array}{l}-0.014 \\
(0.050)\end{array}$ & $\begin{array}{c}-0.027 \\
(0.196)\end{array}$ \\
\hline Atlantic $\times$ Civil War & $\begin{array}{c}-0.230^{* *} \\
(0.115)\end{array}$ & $\begin{array}{c}-0.290^{* * * *} \\
(0.063)\end{array}$ & $\begin{array}{c}-0.228^{* * *} \\
(0.046)\end{array}$ & $\begin{array}{c}-0.161^{* * *} \\
(0.044)\end{array}$ & $\begin{array}{c}-0.173^{* * *} \\
(0.028)\end{array}$ & $\begin{array}{c}-0.224^{*} \\
(0.125)\end{array}$ \\
\hline Vessel tons & & & & $\begin{array}{c}-0.001^{* * *} \\
(0.000)\end{array}$ & $\begin{array}{c}-0.001^{* * *} \\
(0.000)\end{array}$ & $\begin{array}{c}-0.002^{* * *} \\
(0.000)\end{array}$ \\
\hline Number in crew & & & & $\begin{array}{c}-0.013^{* * *} \\
(0.004)\end{array}$ & $\begin{array}{c}-0.013 \\
(0.008)\end{array}$ & $\begin{array}{c}-0.035^{* * *} \\
(0.011)\end{array}$ \\
\hline Percent crew illiterate & & & & $\begin{array}{c}-0.002^{* *} \\
(0.001)\end{array}$ & $\begin{array}{c}-0.002^{* *} \\
(0.001)\end{array}$ & $\begin{array}{c}-0.001 \\
(0.002)\end{array}$ \\
\hline Sailor Effects & $\mathrm{N}$ & $\mathrm{Y}$ & $\mathrm{Y}$ & $\mathrm{Y}$ & $\mathrm{Y}$ & $\mathrm{Y}$ \\
\hline Merchant Effects & $\mathrm{N}$ & $\mathrm{N}$ & $\mathrm{Y}$ & $\mathrm{Y}$ & $\mathrm{Y}$ & $\mathrm{Y}$ \\
\hline Addn'l Vessel Characteristics & $\mathrm{N}$ & $\mathrm{N}$ & $\mathrm{N}$ & $\mathrm{Y}$ & $\mathrm{Y}$ & $\mathrm{Y}$ \\
\hline Sample & Full & Full & Full & Full & Restr. & Full \\
\hline Ownership Shares Included & $\mathrm{N}$ & $\mathrm{N}$ & $\mathrm{N}$ & $\mathrm{N}$ & $\mathrm{N}$ & $\mathrm{Y}$ \\
\hline Rank \& Secondary Rank Effects & $\mathrm{Y}$ & $\mathrm{Y}$ & $\mathrm{Y}$ & $\mathrm{Y}$ & $\mathrm{Y}$ & $\mathrm{Y}$ \\
\hline Year Effects & $\mathrm{Y}$ & $\mathrm{Y}$ & Y & $\mathrm{Y}$ & $\mathrm{Y}$ & $\mathrm{Y}$ \\
\hline Observations & 8,141 & 8,141 & 8,141 & 8,118 & 7,452 & 7,938 \\
\hline \multicolumn{7}{|c|}{$\begin{array}{l}\text { Note: Standard errors, adjusted for clustering on the } 168 \text { merchants in the sample, in parentheses. }{ }^{* * *},{ }^{* *} \text {, and }{ }^{*} \\
\text { denote significance at } 1 \%, 5 \% \text {, and } 10 \% \text {, respectively. A constant term (not shown) is also included. "Additional } \\
\text { Vessel Characteristics" denotes the inclusion of indicator variables for a vessel rigged as a bark, ship, or brig (with } \\
\text { schooner the excluded category); and indicator variables for tender vessels, and for vessels that had tenders. The } \\
\text { "Restricted Sample"-column (5) - deletes observations where the identity of the individual sailor was ascertained } \\
\text { using age, complexion, rank, and/or voyage information. "Ownership Shares Included," column (6), denotes the } \\
\text { case where the (approximate) fraction of output that the vessel ownership shares of masters(where available) entitles } \\
\text { them to is added to the dependent variable. "Rank Effects" denotes the inclusion of indicator variables for the rank } \\
\text { of the crewmembers--master, first officer, second officer, etc.- -and "Secondary Rank Effects" denotes the inclusion } \\
\text { of indicator variables for the second ranks held by crewmembers-cooper, keeper, blacksmith steward, carpenter, } \\
\text { and boatsteerer, as well as an indicator variable for a master with prior experience. }\end{array}$} \\
\hline
\end{tabular}

in differences between Atlantic voyages and other voyages in the pre-war and war periods, respectively, compared to the post-war period; examining these periods separately may help distinguish between trends throughout the sample period, and effects observed within the Civil War only.

In column (1), a regression analogous to the dashed line in the figure is presented: fixed effects for sailors or merchants were not included, nor were any of the vessel or crew characteristics. The interaction term between the Atlantic Ocean and the Civil War period is negative and statistically significant, and its value, -0.23 percentage points of output is equivalent to about $8 \%$ of the mean value of the sailors' shares. In column (2), fixed 
effects for the individual sailors are added, and the difference-in-differences for the Atlantic during the war becomes larger, increasing to -0.29 percentage points of output, implying that failing to take into account selection among the sailors understated the degree of the risk-incentives trade-off. This is consistent with less risk-averse individuals selecting into these voyages during the war, although selection on other characteristics, such as the individual cost of effort, can not be ruled out. In both columns, and throughout the other specifications presented in the table, the interaction term between the pre-war era and the Atlantic is small and statistically insignificant, again indicating that the effect found for the Civil War is not part of some general process of change throughout the sample period.

Column (3) adds fixed effects for the merchants who managed the voyages in the sample. If, during the war, the more risk-averse merchants stopped sending their vessels to the Atlantic, or exited the industry, then omitting these fixed effects should result in an overstatement of the magnitude of the risk-incentives trade-off. The inclusion of these variables does indeed decrease the size of the estimated negative effect of the Civil War period for Atlantic voyages, consistent with selection among less risk-averse merchants into riskier Atlantic voyages during the war. However, once again selection on other characteristics, such as monitoring costs, can not be ruled out.

Column (4) adds controls for various vessel and crew characteristics. These include variables that measure the scale of the voyage, such as the size of the vessel and of the crew, as well as a measure of crew literacy, and binary variables for the configuration of the rigging (not shown), which may have influenced the size and organization of the crew. ${ }^{45}$ The estimated effect of the size of the vessel, and of the size of the crew, are both negative, indicating a negative effect of the scale of the voyage on the individual sailors' shares. The inclusion of these variables further reduces the size of the estimated effect of the Civil War on Atlantic voyages, reducing its effect to -.16 percentage points of output, although the estimate remains highly significant. Evidently, omitting voyage characteristics overstated the degree of the trade-off.

Columns (5) and (6) report estimates from specifications using slightly different versions of the dataset. Column (5) presents a specification that deletes all observations correspond-

\footnotetext{
${ }^{45}$ Contemporary observers were aware of a relationship between vessel size and shares paid; one merchant in Wilmington, Delaware, who considered entering the whaling business, found out from his correspondents in New Bedford that the shares paid to a whaling master varied "in proportion to the size of the vessel, and to his experience and qualifications," Wilmington Gazette (29 October 1833.)
} 
Table 4:

Regressions: Shares

The Dependent Variable is Share, in \% of Output

\begin{tabular}{|c|c|c|}
\hline & Table 3 & ification: \\
\hline & Column (3) & Column (4) \\
\hline Master $\times$ Atlantic $\times$ pre-war & $\begin{array}{l}-0.065 \\
(0.196)\end{array}$ & $\begin{array}{l}0.036 \\
(0.181)\end{array}$ \\
\hline Master $\times$ Atlantic $\times$ Civil War & $\begin{array}{l}-0.356^{* * *} \\
(0.089)\end{array}$ & $\begin{array}{c}-0.319^{* * *} \\
(0.096)\end{array}$ \\
\hline First officer $\times$ Atlantic $\times$ pre-war & $\begin{array}{l}0.141 \\
(0.134)\end{array}$ & $\begin{array}{r}0.270^{* *} \\
(0.112)\end{array}$ \\
\hline First officer $\times$ Atlantic $\times$ Civil War & $\begin{array}{c}-0.372^{* * *} \\
(0.082)\end{array}$ & $\begin{array}{c}-0.302^{* * *} \\
(0.084)\end{array}$ \\
\hline Second officer $\times$ Atlantic $\times$ pre-war & $\begin{array}{l}-0.104 \\
(0.116)\end{array}$ & $\begin{array}{l}0.005 \\
(0.107)\end{array}$ \\
\hline Second officer $\times$ Atlantic $\times$ Civil War & $\begin{array}{c}-0.214^{* * *} \\
(0.066)\end{array}$ & $\begin{array}{c}-0.129 * * \\
(0.060)\end{array}$ \\
\hline Third officer $\times$ Atlantic $\times$ pre-war & $\begin{array}{c}-0.206^{* *} \\
(0.092)\end{array}$ & $\begin{array}{l}-0.129 \\
(0.078)\end{array}$ \\
\hline Third officer $\times$ Atlantic $\times$ Civil War & $\begin{array}{c}-0.171^{* *} \\
(0.072)\end{array}$ & $\begin{array}{c}-0.128^{*} \\
(0.068)\end{array}$ \\
\hline Fourth officer and boatsteerer $\times$ Atlantic $\times$ pre-war & $\begin{array}{l}-0.143 \\
(0.099)\end{array}$ & $\begin{array}{l}-0.077 \\
(0.084)\end{array}$ \\
\hline Fourth officer and boatsteerer $\times$ Atlantic $\times$ Civil War & $\begin{array}{c}-0.134^{* *} \\
(0.059)\end{array}$ & $\begin{array}{l}-0.051 \\
(0.049)\end{array}$ \\
\hline
\end{tabular}

ing to cases where the identity of individual sailors could not be determined using their names only - there was an indication of two different sailors having the same name - and this ambiguity was resolved using personal characteristics such as age or appearance. The results of this specification, which eliminates 666 observations from that of column (4), are quite similar, and indicate a slightly larger negative effect of the Civil War on Atlantic voyages.

Finally, column (6) reports estimates from a specification where the output shares of masters is augmented to include the estimated share of output received by the master due 
to any ownership share in his vessel he may have held. ${ }^{46}$ This is measured with considerable noise, and results in the loss of 180 observations. ${ }^{47}$ With this new definition of the dependent variable, the estimated effect of the Civil War on Atlantic voyages remains negative, but the standard error becomes much larger.

The estimated effects of the Civil War presented in table 3 are averages for all ranks. In order to determine whether there was some differential effect across the various ranks in the dataset, table 4 presents estimates from some of the same specifications as above, only with rank-specific interactions between the Atlantic and the pre-war and Civil War periods. In general, these results are similar to those of table 3, although occasionally the pre-war period for Atlantic voyages has a statistically significant effect for some ranks. The relative magnitudes of the effect are generally similar across ranks within each specification; in the specification corresponding to column (4) of table 3 , the effect is generally between 4 to $6.5 \%$ of the mean share for each rank. There does not appear to be any strong evidence that the effect of war risks was confined to particular ranks in the dataset, or was substantially different across ranks.

\subsection{Variation in Risks Over Time During the War}

Over the course of the war, the severity of the threat of capture perceived by Union merchants evolved in response to news of the Confederate naval efforts, and the variation in intensity of the perceived risks should have influenced the division of risks in whaling contracts over the period of the Civil War.

In the early months of the war, the Confederates' efforts at sea were limited mostly to privateers. After some early successes in 1861, the threat posed by these privateers essentially ended in 1862, due to the Union blockade of Southern ports. By mid-1862, one whaling merchant wrote to his captains that he considered the Confederate vessels "near

\footnotetext{
${ }^{46}$ An ownership share in a vessel entitles the holder to a proportionate share of output, net of the shares of the crew, and net of expenses. That is, if a master owns a share $s$ in the vessel, his share of gross output will be $s\left(1-\sum b_{i}\right)$, where the $b_{i}$ 's are the shares paid to the crewmembers on board that vessel. This amount is added to each master's share.

${ }^{47}$ Ownership information was obtained from vessel registers, which were often not kept up-to-date by whaling merchants. For many voyages, the register probably overstated the master's share, as additional investors purchased shares in the vessel after the register was created but before departure. In addition, for many voyages, the sum of the crews shares was not observed, as the shares of some individual crewmembers were not reported. For these voyages, the total of the shares paid to the crew was approximated as $34.7 \%$, the sample mean.
} 
harmless," 48 as the Union navy was by then "so largely augmented," and the seaports of the South were "in our possession." 49 This merchant simply advised his masters to stay clear the Atlantic coast of the southern states on their voyages.

Beginning in late 1862, however, several powerful Confederate cruisers began to appear in the Atlantic, with devastating consequences for the whaling fleet, and news of the predations of these vessels was greeted with fear and outrage in whaling ports. The same merchant who confidently dismissed any threat by the Confederates in July 1862 was reduced to including inspirational platitudes in his letters to captains in 1863:

This morning we have the [CSS] Florida reported at Pernambuco [Brazil] and another steamer outside supposed the [CSS] Alabama - these two vessels have taken and armed several sailing vessels...under the circumstances it is impossible for us to mark out a course for you to purse that could be relied on. As we have before written, Energy and Good Judgement will overcome great obstacles, the greatest of which, in our judgement, is the cunning devices of the Pirates... ${ }^{50}$

The risk of capture in the Atlantic was generally perceived to be greatest during 1863, and then fell during 1864 and 1865, as the Union navy gradually captured the Confederate cruisers.

The amplitude of these fluctuation in perceived relative risks - initial uncertainty in 1861, followed by a diminishment in 1862, a sharp increase in 1863, and then diminishment in 1864 and 1865 - can be quantified using maritime insurance data. Within the records of the legal claims against Britain following the war, a ledger was found which listed all policies issued by two New Bedford insurance agencies that covered war risks. The premia for the risk of capture from the policies were used to estimate the differences in rates charged to Atlantic voyages, and those elsewhere, for each year of the war, in a framework with vessel fixed effects (see section A.4 of the Data Appendix for additional details on these data.) The results are reported in column (1) of table 5, and indicate that the additional war premium for Atlantic voyages reached a peak of nearly $5 \%$ in 1863, and was lower in most other years.

Were these changes reflected in whaling employment contracts? Column (2) of the table presents estimates from a regression where the effect of the Civil War on Atlantic voyages

\footnotetext{
${ }^{48}$ Letter to Capt. Scott, 17 June 1862, Swift \& Allen.

${ }^{49}$ Letter to Capt. Chase, 6 October 1862, Swift \& Allen.

${ }^{50}$ Letter to Capt. Steen, 15 June 1863, Swift \& Allen. Emphasis in original manuscript.
} 
Table 5:

Changes in Relative War Risks, and the

Contractual Response

\begin{tabular}{lcc}
\hline \hline & $\begin{array}{c}\text { Annual Premium, } \\
\text { War Risk (\%), } \\
\text { Atlantic - Other }\end{array}$ & $\begin{array}{c}\text { Change in Officers' } \\
\text { Output Shares, } \\
\text { Atlantic - Other }\end{array}$ \\
\cline { 2 - 3 } Year & $(1)$ & $(2)$ \\
\hline \multirow{2}{*}{1861 (April - December) } & $4.673^{* * *}$ & $-0.169^{*}$ \\
& $(0.578)$ & $(0.102)$ \\
1862 & $2.303^{* * *}$ & -0.038 \\
& $(0.696)$ & $(0.054)$ \\
1863 & $4.934^{* * *}$ & $-0.279^{* * *}$ \\
& $(1.073)$ & $(0.102)$ \\
1864 & 0.863 & $-0.188^{* *}$ \\
& $(0.607)$ & $(0.080)$ \\
& & $-0.189^{* *}$ \\
& $1.991^{* * *}$ & $(0.086)$ \\
& $(0.648)$ & \\
\hline
\end{tabular}

Note: Column (1) reports estimates from a regression of war premia on Atlantic $\times$ year dummies, as well as vessel fixed effects and policy characteristics. See section A.4 of the Data Appendix for details. Column (2) reports estimates from a regression exactly like column (4) of table 3, only with Atlantic-year interactions replacing the Atlantic $\times$ war term.

is permitted to vary across years. The specification of column (4) of table 3 , which includes sailor and merchant fixed effects, and vessel characteristics, is estimated with Atlantic-year interactions replacing the Atlantic $\times$ war term, in order to measure the effect of each year of the war, compared to the post-war period. Consistent with the insurance data, the year 1863 shows the largest effect on sailors' shares, with an average decline of 0.28 percentage points of output. In general, the year-to-year changes in both columns move in similar directions, although they are certainly only roughly correlated. But this evidence is again at least consistent with war risks driving the results observed in the sailors' shares.

\subsection{Advances}

The results presented so far indicate that, in response to the risks of the Civil War, the shares of output paid to sailors occupying the managerial positions onboard whaling vessels fell, as predicted by theory. This would have had the effect of making the compensation of the individuals in these ranks less sensitive to the risks of their voyages.

This reduction in the sailors' shares would be more likely consistent with an improvement 
Table 6:

Regressions: Advances

The Dependent Variable is Advance, in 1855 Dollars

\begin{tabular}{|c|c|c|c|c|}
\hline & (1) & 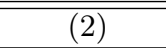 & 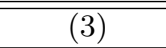 & $\overline{(4)}$ \\
\hline Atlantic & $\begin{array}{c}-35.85^{* * *} \\
(6.03)\end{array}$ & $\begin{array}{c}-26.30 * * * \\
(12.04)\end{array}$ & $\begin{array}{l}-21.30 \\
(13.88)\end{array}$ & $\begin{array}{c}-28.88^{* *} \\
(10.59)\end{array}$ \\
\hline Atlantic $\times$ pre-war & $\begin{array}{c}-50.15^{* * *} \\
(17.28)\end{array}$ & $\begin{array}{c}-112.54^{* * *} \\
(32.10)\end{array}$ & $\begin{array}{c}-121.45^{* * *} \\
(22.22)\end{array}$ & $\begin{array}{c}-105.17^{* * *} \\
(14.72)\end{array}$ \\
\hline Atlantic $\times$ Civil War & $\begin{array}{c}22.54^{* * *} \\
(6.37)\end{array}$ & $\begin{array}{c}28.41 * * * \\
(7.27)\end{array}$ & $\begin{array}{l}20.21^{*} \\
(11.45)\end{array}$ & $\begin{array}{c}20.71 * * * \\
(8.76)\end{array}$ \\
\hline Vessel tons & & & & $\begin{array}{c}-0.25^{* *} \\
(0.10)\end{array}$ \\
\hline Number in crew & & & & $\begin{array}{c}2.57 \\
(2.31)\end{array}$ \\
\hline Percent crew illiterate & & & & $\begin{array}{c}0.03 \\
(0.53)\end{array}$ \\
\hline Sailor Effects & $\mathrm{N}$ & $\bar{Y}$ & $\bar{Y}$ & $\mathrm{Y}$ \\
\hline Merchant Effects & $\mathrm{N}$ & $\mathrm{N}$ & Y & $\mathrm{Y}$ \\
\hline Addn'l Vessel Characteristics & $\mathrm{N}$ & $\mathrm{N}$ & $\mathrm{N}$ & $\mathrm{Y}$ \\
\hline Share of Output & Y & $\mathrm{Y}$ & $\mathrm{Y}$ & $\mathrm{Y}$ \\
\hline Rank Effects & Y & $\mathrm{Y}$ & Y & $\mathrm{Y}$ \\
\hline Year Effects & Y & $\mathrm{Y}$ & $\mathrm{Y}$ & $\mathrm{Y}$ \\
\hline Observations & 1,004 & 1,004 & 1,004 & 1,004 \\
\hline
\end{tabular}

Note: Standard errors, adjusted for clustering on the 23 merchants in this sample, in parentheses. ${ }^{* *}, * *$, and $*$ denote significance at $1 \%, 5 \%$, and $10 \%$, respectively. "Additional Vessel Characteristics" denotes the inclusion of indicator variables for a vessel rigged as a bark, ship, or brig (with schooner the excluded category). 
in their welfare if it were accompanied by some change in their guaranteed compensation. An increase in the advances given to the crews could have fulfilled this function: although the amount borrowed had to be repaid on the completion of the voyage, if the sailors' shares of output were insufficient to repay the advance - due, for example, to a voyage that was not completed, or one that generated little output - the balance owed was generally not repaid. The courts at the time agreed with this interpretation of the advance. In the Massachusetts District Court case Hazard vs. Howland (1863), the court held that "there is no claim for repayment till then [completion], if at all, in case the voyage does not amount to so much" (p. 930). The sailors' advances therefore provided a guaranteed minimum level of compensation, irrespective of the success of the voyage. If this increased for Atlantic voyages during the Civil War, this would be a strong indication of an optimal response to increased risk in the industry's contracts.

Table 6 presents the results of regressions similar to those specified in equation (3), only with the real value of the advance as the dependent variable. The sample is restricted to the 1,004 observations for which the advance could be found; see section A.3 of the Data Appendix for discussion of the representativeness of this sample. However, it is important to note that within this sample, the results presented above for the response of the shares of output to the risks of the war also hold, with very similar magnitudes, although less statistical precision. ${ }^{51}$

The results indicate positive effect of the Civil War on Atlantic voyages of slightly more than $\$ 20$, compared to the post-war period. The introduction of individual sailor fixed effects (column (2)) increases the estimated effect of the Civil War on Atlantic voyages, which is consistent with less risk-averse sailors selecting into these voyages during the war. Columns (3) and (4) introduce merchant fixed effects and vessel and crew characteristics, which reduce the estimated coefficient of the Atlantic $\times$ war term. The estimated impact of Atlantic voyages in the pre-war period, however, is very large and statistically significant in every specification. This is an indication that, compared to the prewar period, advances during the war rose by much more than $\$ 20$ for Atlantic voyages. But it also implies that whatever changes occurred during the war to the relative value of advances were not fully

\footnotetext{
${ }^{51}$ For example, the estimated coefficient on the Atlantic $\times$ Civil War term in the specification of column (4) in table 3 changes from -0.161 (s.e. 0.044 ) to -0.175 (s.e. 0.108 ) when the sample is restricted to the 1,004 observations where advances were known.
} 
reversed after the war, as was the case with the sailors' output shares. This may be an indication that the sailors' advances were somehow "sticky" in adjusting downward after the war, although it may also be due to the noisy, and limited, nature of the sample.

\section{Robustness of The Results}

\subsection{Were there Differential Labor Market Changes During the War?}

An alternative explanation of the findings of this paper is that somehow the market for seamen on Atlantic voyages was affected differentially (say, due to a shift in labor supply arising from unemployed seamen from other maritime industries, who might have preferred voyages to the Atlantic.) This story would result in a fall in relative wages on Atlantic voyages due to the relative "slackness" in that segment of the labor market.

In order to investigate this possibility, an index of labor market tightness that could be observed at the level of individual voyages was constructed from the labor contracts in the dataset. It was sometimes the case that sailors would enlist on a particular whaling voyage, and then run off before its departure, leaving the merchants in need of additional hands. When this occurred, the name of crewmember who abandoned the voyage before it departed would be crossed out on the crew's contract. ${ }^{52}$ If the rate at which crewmembers deserted prior to departure was related to the tightness of the labor market (the assumption being that these abandonments occurred at least sometimes because the sailor received a better offer on a different voyage), then this data might be used as an index of labor market tightness. The relative shifts in an index based on this data could then give an indication of differential conditions in the labor market for sailors on Atlantic voyages. ${ }^{53}$ Summary statistics for the index were presented in table 2: the mean value for the index is around 1.5 sailors per voyage.

Table 7 reports estimates from regressions of this index on interactions between Atlantic voyages and the pre-war and Civil War period. In general, this difference does not seem to behave any differently during the Civil War period, compared to the pre- and post-Civil War periods.

\footnotetext{
${ }^{52}$ Frequently, additional notations were made next to the name, such as "he run off" or "don't go."

${ }^{53}$ It should be noted that, within the simple framework presented above, the change in labor market conditions captured by the index should be reflected in a change in the value of sailors' reservation utilities, and therefore should be reflected in their guaranteed compensation only.
} 
Table 7:

Labor Market Conditions

The Dependent Variable is Number of Sailors Deserting Before Departure

\begin{tabular}{|c|c|}
\hline Atlantic & $\begin{array}{c}-0.146 \\
(0.179)\end{array}$ \\
\hline Atlantic $\times$ prewar & $\begin{array}{c}0.443 \\
(0.277)\end{array}$ \\
\hline Atlantic $\times$ Civil War & $\begin{array}{c}0.195 \\
(0.253)\end{array}$ \\
\hline Number in crew & $\begin{array}{c}0.030^{* *} \\
(0.013)\end{array}$ \\
\hline Merchant Effects \& Year Effects & $\mathrm{Y}$ \\
\hline Observations & 1,154 \\
\hline
\end{tabular}

\subsection{Did Atlantic Voyages Change During the War?}

In response to the elevated risks of the Civil War, whaling merchants may have managed Atlantic voyages differently, and in ways that may have affected the optimal shares paid to the crews. For example, suppose that in response to the presence of Confederate cruisers, whaling voyages to the Atlantic began to follow different routes through that ocean, changing their mix of whaling grounds, or the prey they pursued. Alternatively, the merchants sponsoring Atlantic voyages may have somehow configured or supplied their vessels differently, to prepare them for longer periods away from ports, where the cruisers might have been lurking. If these changes reduced the productivity of the crews' effort, then their shares should have fallen.

One way to investigate whether this occurred is to look for changes in the vessel, crew, and voyage characteristics for Atlantic voyages (relative to others), during the war. Such a comparison is given in table 8 , which presents results of regressions of various voyage characteristics on interaction terms between the Atlantic and the pre-war and Civil war periods. Regressions for each characteristic are estimated with and without fixed effects for the 168 different merchants in the sample, so that the role of changes in the composition of merchants managing Atlantic voyages can be ascertained.

The results in the table indicate that in many respects, Atlantic whaling voyages differed 


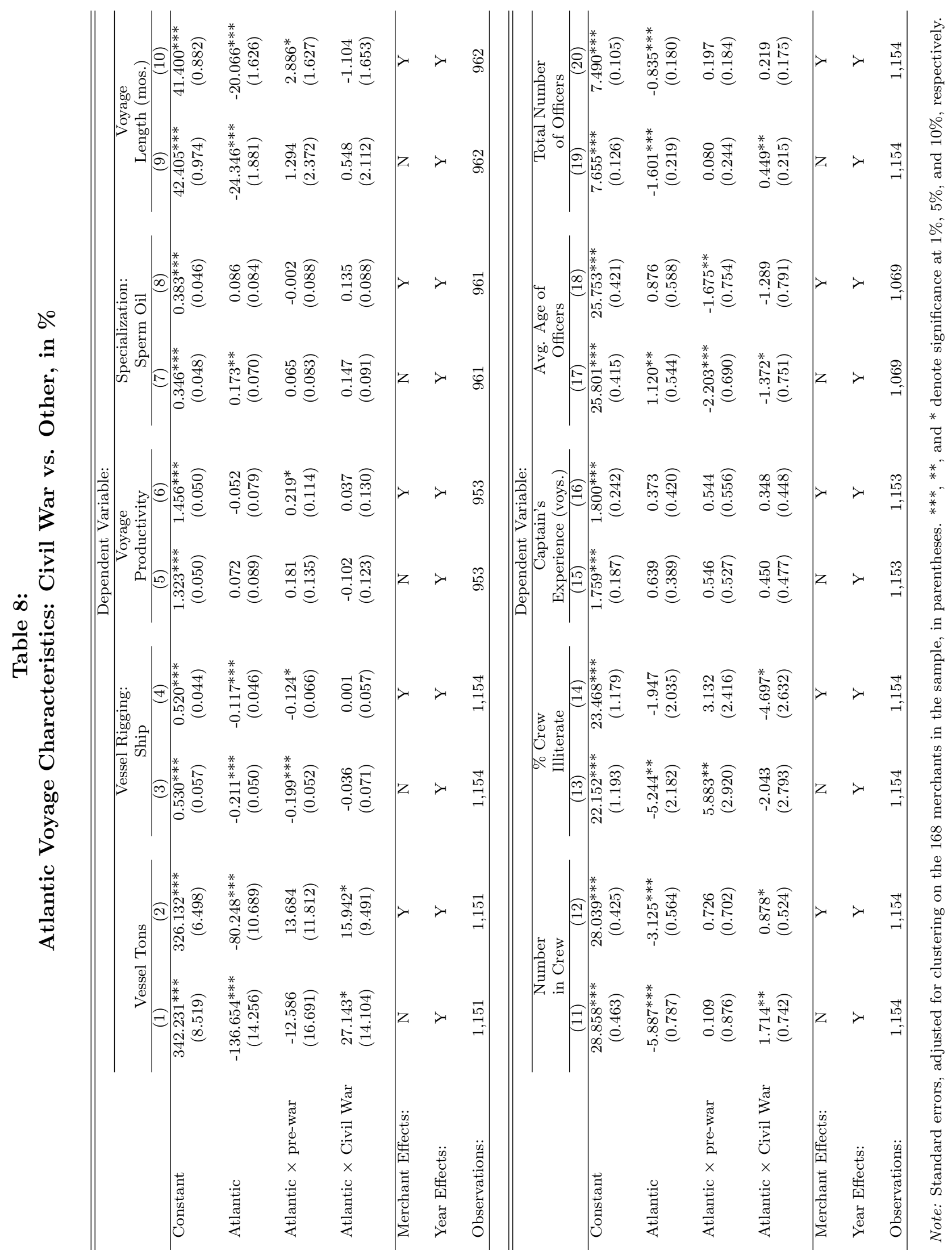


from their counterparts venturing elsewhere - they used smaller vessels with smaller crews, their durations were shorter, and they were somewhat more likely to specialize in obtaining sperm oil. But these differences mostly remained stable during the war, and those that do change appear to do so as a result of the changing composition of merchants - the withinmerchant differences are usually much smaller.

Although it is not possible to obtain consistent measures of the precise itineraries of voyages within particular oceans, the relative propensity to specialize in sperm oil, and voyage length (for completed voyages) are at least related to the voyage itinerary, and these do not appear to change for Atlantic voyages during the war (columns 7-10). More importantly, the relative value of the index of productivity (columns 5-6) did not change for Atlantic voyages during the war, implying that any unobservable changes in itineraries (or other voyage characteristics) did not result in changes in productivity, and were therefore unlikely to have influenced the optimal shares paid to the crews.

The Atlantic voyage characteristics that do seem to change during the war are the vessel size, which increases by 16 tons, and the crew size, which increases by nearly one person. These changes are not large compared to the means of 206 tons and 23 crewmembers for Atlantic voyages throughout the sample, but they may be important. This is consistent with the large effect of including these variables on the estimated risk-incentive trade-off.

\subsection{Falsification Tests}

To further evaluate whether the results presented in this paper for the compensation of sailors during the Civil War are due to the mechanism assumed-riskier voyages in the Atlantic during the period - this section presents some simple falsification tests. The Civil War should not have had an effect on the compensation of sailors on whaling vessels of different sizes, for example, nor should it have had an effect based on the type of prey pursued. If the shares paid on voyages in vessels of a particular size, or which pursued a particular type of prey, changed during the Civil War, this would be an indication that the war had other effects on whaling voyages, which might be responsible for the results. (The results of this latter test are particularly important, as Atlantic voyages were pursued in smaller vessels than those to other oceans.)

Table 9 presents results from these falsification tests. In column (1), the effect of the 
Table 9:

Falsification Tests

The Dependent Variable is Share, in \% of Output

\begin{tabular}{|c|c|c|c|}
\hline \multicolumn{3}{|c|}{$(1)$} & \multirow{2}{*}{$\begin{array}{c}(2) \\
-0.004 \\
(0.049)\end{array}$} \\
\hline Sperm whaling voyage & $\begin{array}{c}0.018 \\
(0.041)\end{array}$ & Small vessel & \\
\hline Sperm whaling voyage $\times$ prewar & $\begin{array}{c}0.015 \\
(0.055)\end{array}$ & Small vessel $\times$ prewar & $\begin{array}{c}0.105^{*} \\
(0.054)\end{array}$ \\
\hline Sperm whaling voyage $\times$ Civil War & $\begin{array}{l}-0.057 \\
(0.054)\end{array}$ & Small vessel $\times$ Civil War & $\begin{array}{c}-0.034 \\
(0.043)\end{array}$ \\
\hline Individual, Rank \& Year Effects & $\mathrm{Y}$ & Individual, Rank \& Year Effects & $\bar{Y}$ \\
\hline Merchant Effects \& Vessel Characteristics & $\mathrm{Y}$ & Merchant Effects \& Vessel Characteristics & $\mathrm{Y}$ \\
\hline Observations & 6,803 & Observations & 8,118 \\
\hline \multicolumn{4}{|c|}{$\begin{array}{l}\text { Note: Standard errors, adjusted for clustering on the } 168 \text { merchants in this sample, in parentheses. } * * * \text {, } \\
* * \text {, and } * \text { denote significance at } 1 \%, 5 \% \text {, and } 10 \% \text {, respectively. The loss of observations in column }(1) \text { is } \\
\text { due to the fact that the variable for sperm whaling voyages is defined ex post, and therefore can not be } \\
\text { measured for voyages that did not return. }\end{array}$} \\
\hline
\end{tabular}

Civil War period on the shares paid on sperm whaling voyages is presented in the context of a specification exactly like that of column (4) of table 3, only with the Atlantic Ocean variable replaced by an indicator variable for voyages that specialized in the pursuit of sperm oil. The estimated effect is very small and is statistically indistinguishable from zero. In column (2), a specification with an indicator for small vessels, defined as those equal to the sample mean tonnage or less, is used. Again, a very small and statistically insignificant result is found.

\section{Discussion and Conclusion}

This paper has endeavored to determine whether or not there was a trade-off between risk and incentives in the employment contracts of the nineteenth-century whaling industry. During the Civil War, Confederate cruisers pursued the commercial vessels of the Union primarily in the Atlantic Ocean, and the identification strategy of the paper utilized this episode of differentially elevated risks for Atlantic whaling voyages to measure the response of the industry's contracts. Whaling crews were paid in shares of their vessels' output, and the results indicate that the crews' shares fell in response to the increase in risk during the 
war, which is consistent with the predictions of the standard theory of contracts. Moreover, the advances received by sailors, which in effect created a guaranteed minimum level of compensation, increased in response to risk, also consistent with the theory.

The results highlight the importance of risk in influencing not only the terms of contracts, but also the characteristics of the individuals observed as contracting parties. In particular, the results are consistent with less risk-averse sailors (agents) and merchants (principals) selecting into riskier voyages, and indicate that the effect of these forms of selection on the observed sensitivity of incentives to risk may be substantial.

There is considerable disagreement regarding the empirical relationship between risk and incentives in compensation contracts. The results of this paper indicate that some of the ambiguity in the findings of the literature may be due to the failure to account for changes in other determinants of contracts that may result from a change in risk. Importantly, the analysis has shown that the results of such omissions may either over- or understate the extent of the trade-off between risk and incentives. 


\section{Bibliography}

Ackerberg, Daniel, and Maristella Botticini. 2002. "Endogenous Matching and the Empirical Determinants of Contract Form," Journal of Political Economy, 110(3), 564-591.

Aggarwal, Rajesh, and Andrew Samwick. 1999. "The Other Side of the Trade-off: The Impact of Risk on Executive Compensation," Journal of Political Economy, 107(1), 65-105.

Allen, Douglas W. 2002. "The British Navy Rules: Monitoring and Incompatible Incentives in the Age of Fighting Sail," Explorations in Economic History, 39, 204-231.

Allen, Douglas W., and Dean Lueck. 1999. "The Role of Risk in Contract Choice," Journal of Law, Economics and Organization, 15, pp. 704-736.

Allen, Robert C. and Ian Keay. 2004. "Saving the Whales: Lessons from the Extinction of the Eastern Arctic Bowhead," Journal of Economic History, 64, 400-432.

Baker, George, and Brian Hall. 2004. "CEO Incentives and Firm Size," Journal of Labor Economics, 22, 767-798.

Bertrand, Marianne, Duflo, Esther, and Sendhil Mullainathan. 2004. "How Much Should we Trust Difference-in-Difference Estimates?" Quarterly Journal of Economics, 119(1), 249-75.

Browne, J. Ross. 1846. Etchings of a Whaling Cruise. New York: Harper \& Brothers.

Cheever, Henry T. 1850. The Whale and His Captors. New York: Harper \& Brothers.

Chiappori, Pierre-Andre, and Bernard Salanie. 2003. "Testing Contract Theory: A Survey of Some Recent Work," in Dewatripont, Hansen, and Turnovsky, eds., Advances in Economics and Econometrics: Eighth World Congress. Cambridge: Cambridge University Press, 115-49.

Coffin, Micajah. 1773. Manuscript letter, August 13. Nantucket Historical Society, Coll. 36, F. 3.

Court of Commissioners of Alabama Claims. 1882-85. Records Relating to Civil War Claims, U.S. and Great Britain. U.S. National Archives, Record Group 76.

Davis, Lance E., Gallman, Robert E., and Karin Gleiter. 1997. In Pursuit of Leviathan: Technology, Institutions, Productivity and Profits in American Whaling, 1816-1906. Chicago: The University of Chicago Press.

Ellickson, Robert C. 1989. "A Hypothesis of Wealth-Maximizing Norms: Evidence from the Whaling Industry," Journal of Law, Economics, and Organization, 5, 83-92.

Hazard v. Howland. 11 F. Cas. 928 (D.C. Mass 1863) (No. 6280).

Hilt, Eric. 2006. "Incentives in Corporations: Evidence from the American Whaling Industry." Journal of Law and Economics, forthcoming.

Hohman, Elmo P. 1928. The American Whaleman. New York: Longmans, Green \& Co.

Holmstom, Bengt, and Paul Milgrom. 1987. "Aggregation and Linearity in the Provision of Intertemporal Incentives," Econometrica, 55, 303-28. 
1991. "Multitask Principal-Agent Problems: Incentive Contracts, Asset Ownership, and Job Design," Journal of Law, Economics, and Organization, 7, 24-52.

Hoover, Ethel D. 1960. "Prices in the 19th Century," in Studies in Income and Wealth, 24.

Karpoff, Jonathan M. 2001. "Public versus Private Initiative in the Artic Exploration," Journal of Political Economy 109, 38-78.

Lund, Judith N. 2001. Whaling Masters and Whaling Voyages Sailing from American Ports: A Compilation of Sources. New Bedford: The New Bedford Whaling Museum.

Morison, Samuel Eliot. 1979. The Maritime History of Massachusetts, 1783-1860. Boston: Northeastern University.

Nimmo, Joseph. 1870. Report to the Secretary of the Treasury in relation to the foreign commerce of the United States and the decadence of American shipping. Washington: U.S. Govt. Print. Off.

Nordhoff, Charles. 1895. Whaling and Fishing. New York: Dodd, Mead \& Co.

Prendergast, Canice. 1999. "The Provision of Incentives in Firms," Journal of Economic Literature, 37, 7-63.

—. 2002. "The Tenuous Trade-off between Risk and Incentives," Journal of Political Economy, 110 (5), 1071-1102.

Republican Standard, New Bedford. 1850-70.

Semmes, Raphael. 1869. Memoirs of service afloat, during the war between the states. Baltimore: Kelly, Piet \& Co.

Scharf, J. Thomas. 1887. History of the Confederate States Navy, from its Organization to the Surrender of its Last Vessel. New York: Rogers \& Sherwood.

Starbuck, Alexander. 1878. History of the American Whale Fishery from Its Earliest Inception to the Year 1876. Waltham, MA: Published by the Author.

Survey of Federal Archives, Works Progress Administration. 1940. Ship Registers of New Bedford, Massachusetts, 1796-1850. Boston, MA: The National Archives Project.

Swift \& Allen. Manuscript letter books, ledgers, journals, and accounts current, 1855-1870. New Bedford Whaling Museum, colls. 5 and 78.

Ulibarri, George S., and Daniel T. Goggin. 1962. "Records Relating to Civil War Claims: United States and Great Britain." Preliminary Inventories, Number 135. Washington: The National Archives.

United States Department of State. 1871. List of claims filed with the Department of state, growing out of the acts committed by the several vessels, which have given rise to the claims generically known as the Alabama claims. Washington: U.S. Govt. Print. Off.

U.S. Naval War Records Office. 1894-1922. Official Records of the Union and Confederate Navies in the War of the Rebellion. Series I, vols. 1-3; Series II, vols. 1-3. Washington D.C.: U.S. Government Printing Office.

Whalemen's Shipping List and Merchants' Transcript, New Bedford. 1850-70. 


\section{A. Data Appendix}

In this Appendix, I first describe the sources and definitions of the data. This is followed by a description of the panel dimensions of the dataset, and a discussion of how individuals were matched over time; data regarding the representativeness of the sample of voyages from which the sailors' advances were obtained; and a description of the data and methodologies used in computing the additional insurance premia for Atlantic voyages during the war.

\section{A.1 Data Sources and Definitions}

\begin{tabular}{|c|c|c|}
\hline Variable & Source & Definition and Notes \\
\hline $\begin{array}{l}\text { Sailors } \\
\text { Name }\end{array}$ & $\begin{array}{l}\text { Manuscript "Shipping Papers," Na- } \\
\text { tional Archives and New Bedford } \\
\text { Whaling Museum, and Manuscript } \\
\text { "Seamen's Registers," New Bedford } \\
\text { Port Society (held by New Bedford } \\
\text { Whaling Museum). }\end{array}$ & $\begin{array}{l}\text { Sailor's name, including first, last and } \\
\text { middle initial. Transcribed from the } \\
\text { contracts ("Shipping Papers"), and } \\
\text { corrected using the "Seamen's Regis- } \\
\text { ters." }\end{array}$ \\
\hline Age & Manuscript "Seamen's Registers." & Sailor's age. $N=4,720$. \\
\hline Complexion & Manuscript "Seamen's Registers." & $\begin{array}{l}\text { Sailor's complexion, coded as "light," } \\
\text { "dark," or "black." } N=4,689 \text {. }\end{array}$ \\
\hline Illiterate & Manuscript "Shipping Papers." & $\begin{array}{l}\text { Binary, }=1 \text { if sailor could not sign his } \\
\text { own name on contract. }\end{array}$ \\
\hline Share of Output & Manuscript "Shipping Papers." & $\begin{array}{l}\% \text { of voyage output paid to sailor. } N= \\
8,151 \text {. There were } 8,612 \text { sailors listed } \\
\text { on the contracts in the dataset; for } 5.4 \% \\
\text { their share was not reported. }\end{array}$ \\
\hline Advance & $\begin{array}{l}\text { Manuscript accounting records held } \\
\text { within the New Bedford Whaling Mu- } \\
\text { seum, and the New Bedford Free Public } \\
\text { Library. Deflated using Hoover (1860). }\end{array}$ & $\begin{array}{l}\text { Advance received prior to departure, } \\
\text { expressed in } 1855 \text { Dollars. Sample in- } \\
\text { cludes } 187 \text { voyages, and } N=1,004 \text {. } \\
\text { Voyages originate from New Bedford } \\
\text { only. See the discussion of the repre- } \\
\text { sentativeness of this sample below. }\end{array}$ \\
\hline
\end{tabular}

Master

Number of prior commands Lund (2001).

Number of prior voyages for which an individual sailed as master.

At least one prior command Lund (2001).

Binary, = 1 if master has at least one prior command.

Died on voyage

Lund (2001).

Binary, = 1 if master died during voyage.

Share owned in vessel

Manuscript vessel registers, and Survey of Federal Archives (1940).
Manuscript "Shipping Papers."
Number of sailors on voyage whose primary rank is master, first through fourth officer, or boatsteerer. 


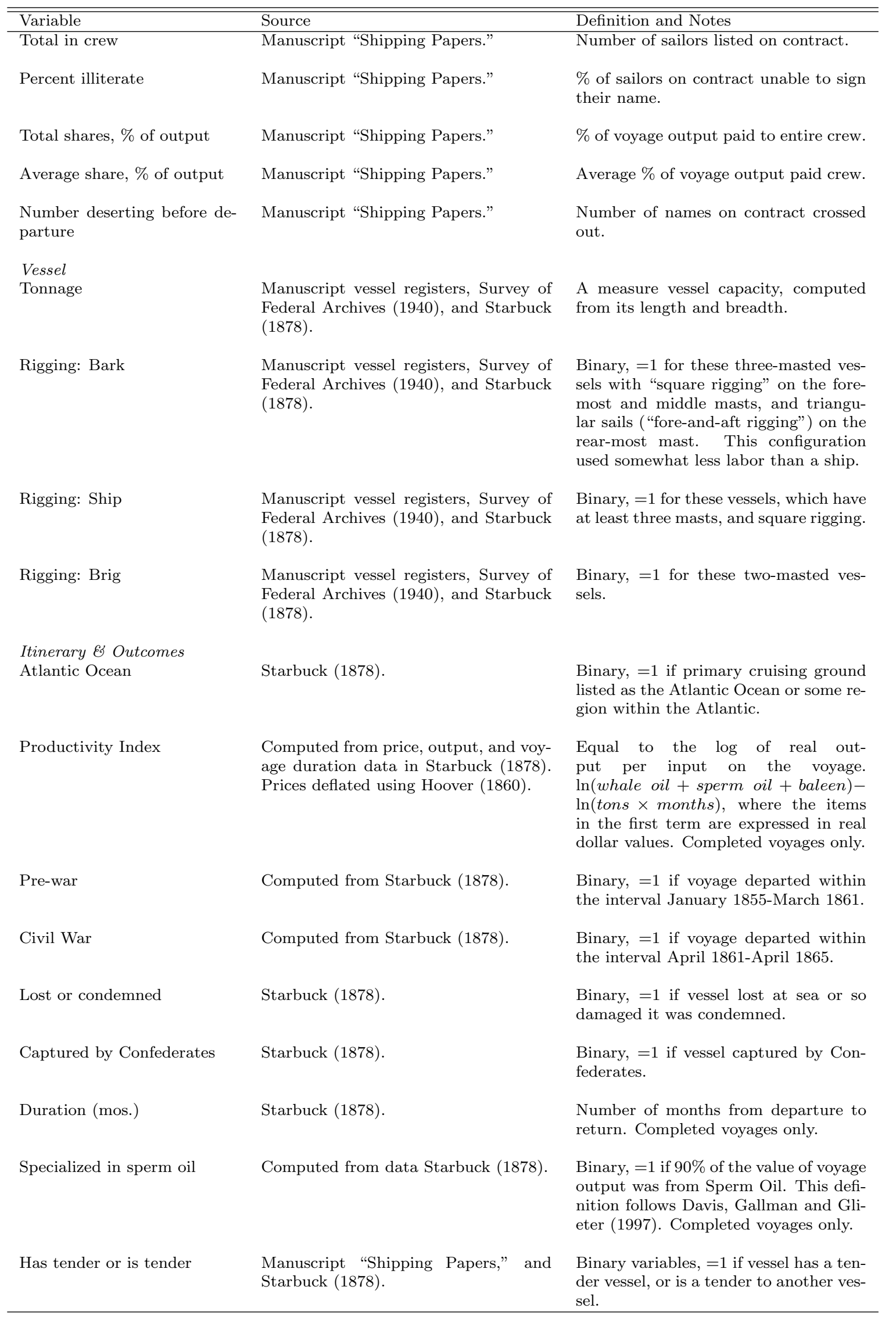




\section{A.2 The Panel of Individuals and Merchants}

Observations were ascribed to individuals on the basis of the name listed; any two or more observations with the same first name, middle initial, and last name were initially regarded as that of the same person. The resulting panel was then examined for individuals who appeared to sail on multiple voyages simultaneously (that is, who departed on a voyage while on board another voyage), or whose rank fell by more than 2 levels in the hierarchy (eg., from master to second officer) or rose by more than 3 , on adjacent voyages. Where possible, these observations were then ascribed to separate individuals with the same name, on the basis of their age, their appearance, the timing of their voyages, and their ranks. All observations where such assignments were made were coded as "artificially assigned to individuals" and excluded from the dataset in robustness checks (see, eg, column (5) in table 3.) If it was not possible to divide the observations with the same name among separate individuals on the basis of this information, each observation with that name was assigned to a separate individual. These observations were also coded as "artificially assigned to individuals" and excluded from the dataset in robustness checks. (The merchants in the dataset presented no such identification problems.)

The observations in the dataset were thus ascribed to 5,378 different individuals, who were observed, on average, on 1.52 voyages, and in 1.21 different ranks. Some simple descriptive statistics of the distribution of the number of voyages performed and ranks held by the individuals in the dataset is presented in the table below.

\begin{tabular}{|c|c|c|c|c|}
\hline & \multicolumn{2}{|c|}{ Ranks: } & \multicolumn{2}{|c|}{ Voyages: } \\
\hline & $\begin{array}{l}\text { Number of } \\
\text { Individuals }\end{array}$ & $\begin{array}{c}\text { Number of } \\
\text { Observations }\end{array}$ & $\begin{array}{l}\text { Number of } \\
\text { Individuals }\end{array}$ & $\begin{array}{c}\text { Number of } \\
\text { Observations }\end{array}$ \\
\hline One & 4,440 & 5,505 & 3,631 & 3,631 \\
\hline Two & 749 & 1,923 & 1,065 & 2,130 \\
\hline Three & 163 & 606 & 443 & 1,329 \\
\hline Four or more & 26 & 117 & 239 & 1,061 \\
\hline Total & 5,378 & 8,151 & 5,378 & 8,151 \\
\hline
\end{tabular}

There are 168 different whaling merchants who sponsored voyages in the dataset; the average number of voyages sponsored by each merchant was 6.9. None of these merchants operated in more than one port. The 13 ports in which these merchants were based were: Dartmouth, Fairhaven, Mattapoisett, Nantucket, New Bedford, Provincetown, Sandwich, Wareham, and Westport, MA; New London, CT; and Sag Harbor and New York, NY.

\section{A.3 The Sample of Advances}

The only records of the advances given to whaling crews were kept within the merchants' accounts, most of which no longer survive. Within the two whaling archives in New Bedford, MA - the Whaling Museum, and the Free Public Library - there are significant holdings of merchants' manuscript accounts; for 24 merchants, records of the advances received by the crews could be found for at least one voyage. The types of records from which advances were obtained were generally one of the following: volumes of accounts kept with individual sailors, lists of indebtedness of crewmembers given to masters at the beginning of voyages, and the bills of outfitting firms, which were paid by the merchant managing a whaling voyage after it departed. In the case of the accounts with sailors, there were frequently entries for money advanced during the voyage, either on board the vessel, or at home, to the sailor's family, but as these amounts were likely contingent on the progress of the voyage, they were excluded from the amount of the advance recorded in the dataset. In most cases, 
the advances given to the master were not found, usually because the accounts with the master were kept separately.

Advances were found for 187 of the 1,156 voyages in the dataset. Given that they originated primarily in New Bedford, these voyages are very typical of New Bedford voyages, but somewhat different from the rest of the sample in a few respects. The following table presents some summary statistics for the sample and compares them to the overall dataset.

\begin{tabular}{lcc}
\hline \hline & $\begin{array}{c}\text { Mean, } \\
\text { Advances Sample } \\
(N=187)\end{array}$ & $\begin{array}{c}\text { Mean, } \\
\text { Other Voyages } \\
(N=969)\end{array}$ \\
\hline Itinerary: Atlantic & 0.31 & 0.33 \\
Itinerary: Pacific & 0.50 & 0.49 \\
Total Pay of Crew, \% of output & 32.1 & 33.4 \\
Average Age of Officers & 26.8 & 27.1 \\
Total in crew & 28.4 & 26.7 \\
Vessel Tons & 324 & 289 \\
\hline
\end{tabular}

In many respects, the voyages in the sample were quite typical of the overall dataset; the voyage itineraries, and the observable characteristics of the crews, were quite similar across the two groups. However, the vessels in the sample were larger than the other voyages' vessels, and they carried slightly larger crews. Again, this is because the sample was taken from New Bedford voyages; the mean vessel tonnage and crew size for the sample were equal to the means of those variables for all New Bedford voyages in the dataset.

\section{A.4 Wartime Insurance Policies}

In the aftermath of the Civil War, the United States held Britain liable for many of the damages inflicted by Confederate cruisers; a treaty, signed in 1871, created a tribunal in Geneva, which eventually awarded the United States $\$ 15.5$ million. In 1874, and then again in 1882, domestic "Courts of Commissioners of Alabama Claims" were created to evaluate claims of U.S. citizens. The latter (1881) Courts of Commissioners were authorized to adjudicate claims for the payment for premiums for war risks (see Ulibarri and Goggin, 1962). Within the records of these claims in the possession of the National Archives (Record Group 76), a ledger was found listing all the policies written by two New Bedford insurance firms covering war risks. There were a total of 443 policies written for whaling voyages during the war, covering 189 different vessels, some of which were in port, and some of which were at sea at the time the policy was written. The voyage itineraries were obtained from Starbuck (1878). Summary statistics for the policy are presented in the table below.

\begin{tabular}{lcccc}
\hline \hline & Mean & Stdev. & Min. & Max. \\
\hline Amount insured, in $\$$ & $3,441.98$ & $3,621.78$ & 150 & 20,000 \\
Coverage includes catchings & 0.38 & - & 0 & 1 \\
Duration of coverage, war risks (yrs.) & 1.36 & 0.54 & 0.41 & 3 \\
Premium per year, war risks, \% & 3.76 & 1.87 & 0.33 & 14.4 \\
Vessel in port & 0.31 & - & 0 & 1 \\
Atlantic voyage & 0.33 & - & 0 & 1 \\
\hline
\end{tabular}

Column (1) of table 5 reports estimates from the regression $w_{s t}=\mathbf{p}_{s t} \lambda+\sum_{t} \eta_{t}$ Atlantic $_{s t} \times$ year $_{t}+\sum_{t} \delta_{t}$ year $_{t}+\sum_{s} \omega_{s}$ vessel $_{s}+u_{s t}$, where $w_{s t}$ is the premium for war risks charged for vessel $s$ in year $t ; \mathbf{p}_{s t}$ is a vector of variables describing the policy, including the amount covered, the duration of the coverage, whether or not the coverage included catchings on board, and whether the vessel was at sea; Atlantic $j t$ is an indicator variable for an Atlantic voyage; $\operatorname{vessel}_{s}$ is an indicator variable for each vessel; and year $t_{t}$ is and indicator variable for each year during the war. The $\eta_{t}$ 's are reported in table 5 . 